\title{
Community-based interventions for enhancing access to or consumption of fruit and vegetables among five to 18-year olds: a scoping review
}

\author{
Rebecca Ganann*, Donna Fitzpatrick-Lewis, Donna Ciliska and Leslea Peirson
}

\begin{abstract}
Background: Low fruit and vegetable ( FV) consumption is a key risk factor for morbidity and mortality. Consumption of FV is limited by a lack of access to FV. Enhanced understanding of interventions and their impact on both access to and consumption of FV can provide guidance to public health decision-makers. The purpose of this scoping review is to identify and map literature that has evaluated effects of community-based interventions designed to increase FV access or consumption among five to 18-year olds.
\end{abstract}

Methods: The search included 21 electronic bibliographic databases, grey literature, targeted organization websites, and 15 key journals for relevant studies published up to May 2011. Retrieved citations were screened in duplicate for relevance. Data extracted from included studies covered: year, country, study design, target audience, intervention setting, intervention strategies, interventionists, and reported outcomes.

Results: The search located 19,607 unique citations. Full text relevance screening was conducted on 1,908 studies. The final 289 unique studies included 30 knowledge syntheses, 27 randomized controlled trials, 55 quasiexperimental studies, 113 cluster controlled studies, 60 before-after studies, one mixed method study, and three controlled time series studies. Of these studies, 46 included access outcomes and 278 included consumption outcomes. In terms of target population, 110 studies focused on five to seven year olds, 175 targeted eight to 10 year olds, 192 targeted 11 to 14 year olds, 73 targeted 15 to 18 year olds, 55 targeted parents, and 30 targeted teachers, other service providers, or the general public. The most common intervention locations included schools, communities or community centres, and homes. Most studies implemented multi-faceted intervention strategies to increase FV access or consumption.

Conclusions: While consumption measures were commonly reported, this review identified a small yet important subset of literature examining access to FV. This is a critically important issue since consumption is contingent upon access. Future research should examine the impact of interventions on direct outcome measures of FV access and a focused systematic review that examines these interventions is also needed. In addition, research on interventions in low- and middle-income countries is warranted based on a limited existing knowledge base.

\section{Background}

Low fruit and vegetable (FV) consumption is one of the top 10 global risk factors for mortality according to the World Health Organization (WHO) [1]. Increased FV consumption can help protect overall health status and reduce both disease risk and burden [2]. Fruit and vegetable intake among children is of particular interest due to growing recognition of the importance of nutrition for

*Correspondence: ganannrl@mcmaster.ca

Effective Public Health Practice Project, McMaster University, Hamilton, ON, Canada growth, development, and prevention of chronic diseases such as cardiovascular disease and obesity [2]. A number of studies have shown that childhood FV consumption patterns and preferences are predictive of patterns in adolescence and adulthood [3-6]. It has been estimated that 2.7 million lives could be saved each year through increased and adequate FV consumption. In addition, this increased consumption of FV would decrease the worldwide non-communicable disease burden by almost $2 \%$ [7].

Consumption of FV is limited by a lack of access to $\mathrm{FV}$, which is a conspicuous issue facing low- and 
middle-income countries, but also affects high-income countries [8]. While FV intake is directly associated with socioeconomic status, many individuals do not meet recommended guidelines for FV intake regardless of country of origin and income status [8]. A systematic review of potential determinants of FV intake and intervention strategies found that availability and accessibility of FV and preferences had the most consistent positive relationship with FV consumption [9]. Another more recent systematic review of determinants of fruit and vegetable consumption among children and adolescents identified many individual level determinants including direct gradients associated with intake and socioeconomic status, home availability and accessibility, and parental intake patterns [8]. The environmental factors that influence consumption of FV extend beyond the individual to include: physical, economic and social factors; supply, availability and accessibility (includes costing); availability of FV in stores in the local community, schools, community-based programs; and policies at global, regional, national and local levels [8-11]. Nutrition knowledge, preferences, and self-efficacy are also associated with increased intake of FV $[8,12,13]$ and therefore have been included as secondary outcomes of interest for this review. Enhanced understanding of relevant intervention research and its impact on both access to and consumption of FV, as well as chronic disease health indicators, can provide guidance to public health decision-makers and policy-makers in the establishment and maintenance of effective and supportive nutritional programs.

Three reviews have previously examined the effect of community interventions to increase FV consumption, however, one review has not been updated in over 10 years [14] and the two others were limited to schoolbased interventions in high-income countries $[15,16]$; in these the previous reviews, the important issue of access to FV was not addressed [14-16]. The purpose of this scoping review is to identify and map literature that has evaluated the effects of community-based interventions designed to increase FV access and/or consumption among five to 18-year olds. The effectiveness of upstream interventions targeting children and adolescents (18 years and under) is of particular interest to decision makers since FV consumption patterns established in childhood tend to persist through adulthood [3-6]. We are aware of a potentially complementary review that intends to examine interventions to increase FV consumption in preschool children (under 5 years) [17] and therefore focused on 5 to 18 year olds. Due to the large scope of this review topic, interventions focused solely on adults or specialized populations such as those with a specific chronic disease were considered beyond the scope of this review.
The initial step in this scoping review involved defining the research question in a PICOS (PopulationIntervention-Comparison-Outcome-Study Design) format. The PICOS question was defined by the research team and refined in collaboration with two public health librarians who subsequently implemented the search.

\section{Methods \\ Inclusion criteria \\ Participants}

This review includes populations from low-, middle-, and high-income countries and focuses on children aged five to 18 years.

Interventions We included interventions delivered to anyone that brings about changes in FV access and consumption for five to 18 year olds (i.e., parents, communities, and others within the population, including children themselves). The following types of community-based interventions were included:

- Nutrition-friendly schools initiatives

- Child nutrition programs such as breakfast/lunch and summer food service programs

- Community programs (e.g., community gardens)

- Health education related to increased FV consumption

- Economic supplements and subsidies to purchase FV, including subsidies for schools and food stamp programs

- Environmental school change strategies (e.g., changing the types of foods provided in cafeterias or vending machines)

- Environmental interventions/industry partnerships focused on point-of-purchase (e.g., restaurants, grocery store distributors and retailers); this might include campaigns to draw attention to healthier products in grocery stores or to highlight the benefits of certain foods or within store promotions and costs

- Population level initiatives (e.g., agricultural policies)

- Internet, telephone and media interventions

- Farm-to-school programs that use locally produced foods

- Social marketing campaigns

- Policies that affect accessibility factors

- Policies that seek to increase FV consumption (i.e., school board level, provincial/national level).

\section{Locations}

Intervention locations included: homes, schools, health departments, religious institutions, family/child centres, community/recreation centres, non-governmental organizations, and primary healthcare settings. We excluded 
programs or strategies delivered through hospitals; outpatient clinics located within hospital settings; commercial programs, such as Health Check; universities/ colleges; and metabolic or weight loss clinics.

\section{Outcomes of interest}

Our primary outcomes included measures of both access to and consumption of fruit, vegetables, or both. Evidence of intervention effects included: measures at individual, family, school or community levels. Measures of FV access included: FV supply (i.e., market inventory); and change in food environments, food disappearance, and food sales (in cafeterias and grocery stores). Food supply measures included information about which food items are distributed to different regions and areas. Market inventory refers to records a food supply organization keeps about which foods are being ordered or are available. Measures of FV consumption included: diet and food intake records, self-reported and/or reported by parents, teachers or both; food frequency questionnaires/balance sheets; food wastage and plate waste; and micronutrient measures (i.e., biomarkers of exposure to FV).

Our secondary outcomes included: awareness of importance/impact of FV consumption among targeted individuals, attitudes towards consumption of FV, general health measures including changes in weight, and adverse outcomes or unintended consequences.

\section{Study designs}

Acceptable designs for this review included systematic reviews (included research syntheses and meta-analyses), randomized and non-randomized studies (including cluster-controlled and controlled time series), interrupted time series (to assess changes that occur over time), and before-after studies with controls. Relevant clusters within studies, included school units, classrooms or communities rather than individuals as the unit of analysis.

\section{Search strategy}

Our search strategy included: electronic bibliographic databases; grey literature databases; reference lists of key articles; targeted internet searching of key organization websites; and hand searching of key journals.

We searched the following databases, adapting search terms according to the requirements of individual databases in terms of subject heading terminology and syntax: MEDLINE and Pre-MEDLINE; EMBASE; CINAHL and Pre-CINAHL; the Cochrane Central Register of Controlled Trials (CENTRAL); the Cochrane Public Health Group Specialized Register; PsycINFO; Dissertation Abstracts; ERIC; Effective Public Health Practice Project Database; Sociological Abstracts; Applied Social Sciences Index; CSA Worldwide Political Science Abstracts; ProQuest (ABI/Inform Global); PAHO Institutional Memory
Database; WHO Database on Child Growth and Malnutrition; Healthstar; Current Contents; ScienceDirect; and LILACS. The original search was conducted on August 17, 2010 and was updated on May 31, 2011, searching each database from its beginning. Our search strategy for the electronic databases is shown in Appendix 1 (Additional file 1).

We used the Grey Matters search tool, Federated Search for applicable policy documents, the System for Grey Literature in Europe and the Global Health Database to search for relevant grey literature. We conducted a hand search of the reference lists of all relevant articles for any additional references. We also searched key sites, including the World Health Organization (http://www. who.int/en/), the Food and Agriculture Organization of the United Nations (http://www.fao.org/), and Pan American Health Organization (http://new.paho.org/). Further, we had searched the following journals (for the 12-month period prior to the date of search [Aug. 17, 2010]): Health Policy; Journal of Public Health Policy; Journal of Health Politics, Policy, and Law; Health Economics, Policy, and Law; American Journal of Clinical Nutrition; Journal of Health Services Research; American Journal of Public Health; Journal of the American Dietetic Association; Nutrition Reviews; Maternal and Child Nutrition; Nutrition and Dietetics; Nutrition Research; Public Health Nutrition; American Journal of Preventive Medicine and Journal of Hunger and Environmental Nutrition. Journal selection for hand searching was guided by consultation with experts and our review advisory committee.

\section{Study selection}

A librarian conducted a search for relevant literature. The search strategy identified titles and abstracts. Teams of two reviewers conducted relevance screening to eliminate obviously irrelevant studies; each person independently reviewed titles and abstracts for relevance screening. All articles selected by either team member were retrieved for full text review. For citations with no abstract, the full article was retrieved for full text relevance screening.

Review teams independently examined the full text of retrieved articles for relevance. A third reviewer was consulted to resolve any disagreements related to inclusion of articles. Studies excluded following full text reviews and reasons for exclusion were documented. Articles in English, French and Spanish were reviewed at the inclusion screening stages (title/abstract and full text review).

\section{Data extraction and sorting}

For all included studies, data were extracted by two reviewers and included: year of publication, study design, types of outcomes reported and research location. When 
there was more than one publication per study, these citations were grouped into 'projects'. Only articles published in English and French underwent data extraction due to the fluency of available reviewers.

\section{Results \\ Citation retrieval}

The search strategy retrieved nearly 23,000 citations, which were reviewed by research assistants to remove duplications. Of the citations identified, 22,287 (97.3\%) were found through published literature databases, 156 (0.7\%) through grey literature searching, and 468 (2.0\%) through hand searching relevant journals. Two reviewers independently examined the titles and abstracts of 19,607 unique citations for relevance. Following title and abstract review, 17,699 (90.3\%) citations were excluded and $1,908(9.7 \%)$ remained to undergo full text relevance screening. Following full text review, 1,619 (84.9\%) studies were excluded with 289 (15.1\%) unique studies remaining. Of the citations excluded during full text review, 52 (3.2\%) were excluded because they were published in a language other than English or French, 366 (22.6\%) had target audiences that did not include children aged five to 18 years or persons who had influence over FV access or consumption for children, 232 (14.3\%) did not use a study design appropriate for evaluating interventions, $638(39.4 \%)$ did not evaluate a relevant intervention or policy, 236 (14.6\%) did not have baseline comparison data, and 95 (5.9\%) did not report outcomes of interest for five to 18 year olds. See Figure 1 for a flowchart of literature retrieved, levels of screening, included studies, and types of outcomes.

The final 289 unique studies were found in the form of journal articles and reports. The published citations appeared in 100 periodicals with 89 published in five journals. These included 12 articles published in the Journal of Nutrition Education \& Behavior, 14 in the Journal of Nutrition Education, 17 in the Journal of the
American Dietetic Association, 19 in Preventive Medicine, and 27 in Public Health Nutrition. The year of publication for included articles ranged from 1970 to 2011, with 230 studies published during or since 2001. See Appendix 2 (Additional file 2) for details of all included studies, such as author(s), title, year, location, design, target population, and types of outcomes measured. As seen in Appendix 2, very few studies from low- or middle-income countries were identified.

\section{Study designs and outcomes}

The final 289 unique studies included 30 knowledge syntheses (including narrative systematic reviews and metaanalyses) [9,14,15,18-44], 27 randomized controlled trials [45-71], 55 quasi-experimental studies [72-126], 113 cluster controlled studies [94,127-237], 60 before-after studies [238-306], one mixed method study [307], and three controlled time series studies [308-310]. Several of studies had multiple publications reporting results (e.g., outcomes reported at different time points): Ammerman et al. $[18,19,311]$, Bere $[139,312,313]$; Bere et al. $[140,314,315]$, Byrd-Bredbenner et al. [146,316], Ciliska et al. [15,317], Chen et al. [48,318], Colby [247,319], Covelli [79,320], Cullen et al. [253,321], Gortmaker et al. [163,322], Haarens et al. [166,323], Hendy et al. [55,324], Hollar et al. [96,325,326], Hopper et al. [174,327], Jimenez et al. [100,328,329], Latimer [273,330], Lautenschlager and Smith [275,331], Lytle et al. [191,332,333], McCormick et al. [285,334], Nicklas et al. [198,335], Parmer et al. [203,336], Reinaerts et al. [217,337], Tak et al. [121,338,339], Tanner et al. [120,340], Taylor et al. $[229,341]$, Thomas et al. [42,342], Thompson et al. [231,232,343], Walker [267,303], Wardle et al. [69,344], and Wrigley [306,345]. The number of citations for each study design and the reported outcome measures are summarized in Table 1 . All study tallies included in the following sections and associated (Tables 2, 3, 4 and 5) include both knowledge syntheses and primary studies.

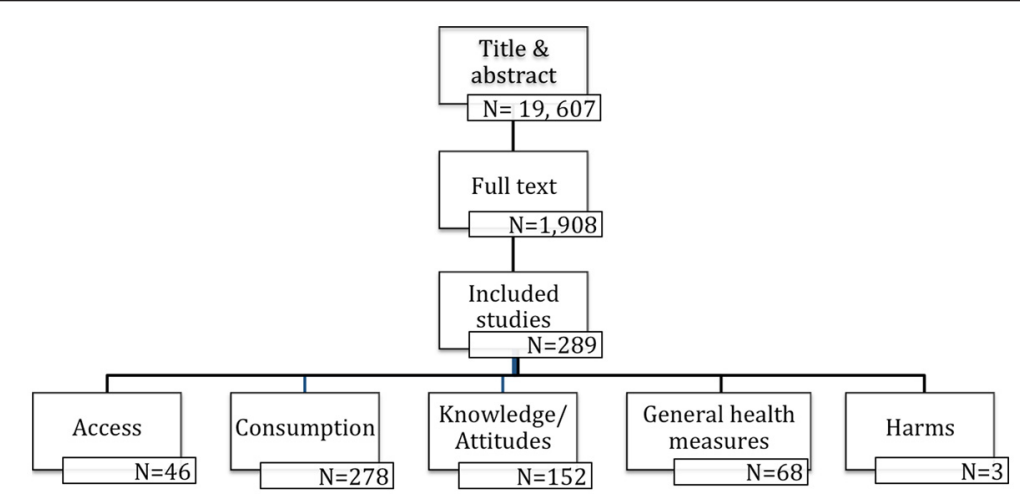

Figure 1 Flowchart of screening process for unique citations retrieved, number of included studies at each level of screening, and outcomes reported in included studies. 
Table 1 Study design and outcomes

\begin{tabular}{|c|c|c|c|c|c|c|}
\hline Study design & Access & Consumption & $\begin{array}{c}\text { Knowledge/ Attitudes/ } \\
\text { Awareness }\end{array}$ & $\begin{array}{c}\text { General health } \\
\text { measures }\end{array}$ & Harms & $\begin{array}{c}\text { Total Studies } \\
\text { by Design }\end{array}$ \\
\hline Systematic Review & 8 & 30 & 18 & 9 & 0 & 30 \\
\hline RCT & 2 & 27 & 14 & 12 & 0 & 27 \\
\hline Quasi-Experimental & 6 & 51 & 26 & 12 & 0 & 55 \\
\hline Cluster Controlled & 11 & 107 & 59 & 25 & 3 & 113 \\
\hline Before-After (no control) & 18 & 59 & 31 & 9 & 0 & 60 \\
\hline Mixed Method & 1 & 1 & 1 & 0 & 0 & 1 \\
\hline Controlled Time Series & 0 & 3 & 3 & 1 & 0 & 3 \\
\hline
\end{tabular}

\section{Intervention target populations and outcomes}

The target audiences for interventions may have included sub-groups within the age range of five to 18 years; however, adults who influence children's nutritional access or consumption may also have been targeted. For interventions that targeted these 'other' audiences, the articles needed to report outcomes for five to 18 year olds to be included in this review. Of the unique studies, 110 targeted five to seven year olds, 175 targeted eight to 10 year olds, 192 targeted 11 to 14 year olds, 73 targeted 15 to 18 year olds, 55 targeted parents, 12 targeted teachers, five targeted other service providers, and 13 targeted the general public. For a breakdown of outcomes reported in both knowledge syntheses and primary studies by target audience see Table 2. Additional file 2 summarizes target audiences for each individual study together with other study features.

\section{Intervention locations and outcomes}

Each unique citation was also examined to identify the locations in which interventions were delivered. Interventions were delivered in a wide variety of locations: schools $(\mathrm{n}=233)$, supermarkets $(\mathrm{n}=9)$, religious institutions $(n=2)$, community or community centres $(n=37)$, camps $(n=7)$, primary care settings $(n=5)$, homes $(n=38)$, by internet $(n=6)$, and other locations $(n=26)$. The other locations included after school programs, Boy and Girl
Scout troop meetings, child care centres, farms or farmers' markets, pediatricians' offices, YMCAs and youth programs. The outcomes measured in various locations of intervention delivery are shown in Table 3 (includes knowledge syntheses and primary studies). Many studies were delivered in multiple locations such as in schools plus community $[30,40,42,100,246,282]$, plus home $[26,31,94,102,110,144,145,154,174,189,197,205,254,281$, $327,346]$, plus supermarkets [137], plus after school programs [43], plus the internet [103], plus other $[9,27,67,195,257,286]$, or schools plus two or more other locations $[19,23,24,29,35-38,88,157,159,161,317]$. Several other studies combined a general community location plus a supermarket [82], camp [265], home $[20,135]$, religious institution [53], other [181], or home plus internet components [231]. Three studies implemented interventions in primary care settings plus the home $[25,62,63]$. Others primarily targeted the home with other components delivered either by internet [251], in other locations [151,231,270], or both [46]. One study delivered an intervention within a religious institution combined and a camp [247].

\section{Intervention strategies and outcomes}

Most studies implemented multi-faceted intervention strategies with only approximately $10 \%$ of studies implementing individual strategies to increase FV access or consumption. An example of a multiple intervention

Table 2 Target audience and outcomes

\begin{tabular}{|c|c|c|c|c|c|}
\hline Audience & Access & Consumption & Knowledge/ Attitudes/ Awareness & General health measures & Harms \\
\hline 5 - 7 year olds & 16 & 109 & 55 & 21 & 1 \\
\hline 8 - 10 year olds & 30 & 175 & 98 & 40 & 3 \\
\hline 11 - 14 year olds & 29 & 187 & 102 & 44 & 3 \\
\hline 15 - 18 year olds & 12 & 71 & 42 & 21 & 0 \\
\hline Parents & 15 & 57 & 33 & 22 & 1 \\
\hline Teachers/ school personnel & 3 & 10 & 9 & 6 & 1 \\
\hline Other service providers & 3 & 3 & 2 & 1 & 0 \\
\hline General public & 6 & 14 & 4 & 2 & 0 \\
\hline
\end{tabular}


Table 3 Intervention locations and outcomes

\begin{tabular}{|c|c|c|c|c|c|}
\hline Location & Access & Consumption & Knowledge/ Attitudes/ Awareness & General health measures & Harms \\
\hline School & 33 & 229 & 130 & 47 & 3 \\
\hline Supermarket & 2 & 9 & 6 & 2 & 0 \\
\hline Religious institution & 0 & 2 & 2 & 1 & 0 \\
\hline Community & 12 & 37 & 22 & 15 & 1 \\
\hline Camps & 2 & 5 & 5 & 2 & 0 \\
\hline Primary care setting & 0 & 5 & 1 & 2 & 0 \\
\hline Home & 9 & 38 & 22 & 10 & 1 \\
\hline Internet & 2 & 5 & 4 & 3 & 0 \\
\hline Other & 5 & 26 & 15 & 9 & 0 \\
\hline
\end{tabular}

strategy is an educational series delivered primarily in a school with an added homework component to engage parents. The outcomes measured using different intervention strategies are shown in Table 4 (knowledge syntheses and primary studies).

\section{Intervention delivery and outcomes}

Unique studies were also examined to determine who had delivered interventions. Most often teachers ( $\mathrm{n}=130)$, school administrators $(\mathrm{n}=32)$ and/or other school personnel $(n=49)$ were involved in delivery. In other cases, dieticians $(n=19)$, health departments or health ministries $(n=11)$, and other health professionals $(n=23)$ were responsible for implementation. Community lay persons and peers were involved in delivering interventions in 12 and 15 studies, respectively. In some studies the researchers implemented the interventions $(\mathrm{n}=13)$, whereas in many others it was not stated who delivered the interventions. A breakdown of the outcomes and by whom the interventions were delivered (knowledge syntheses and primary studies) is summarized in Table 5. Some studies had interventions that were delivered by multiple individuals, such as teachers plus another community or school individual (e.g., administrator, health professional, other school personnel, researcher) $[21,26,29,37,38,41,52,59,72,97,103-105,118,121,131,134$, $137,140,144,157,161,198,200,214,217,218,226,249,258$, $261,274,291,301,309,310,317,338,342]$; teachers plus 2 or more other individuals $[15,23,28,31,36,43,74,75,88,102$, $110,119,127,137,159,166,172,175,199,202,205,213,219,246$, 262,276,299]; Health Department or Ministry of Health together with school administrators or other school

Table 4 Intervention strategies and outcomes

\begin{tabular}{|c|c|c|c|c|c|}
\hline Intervention Strategy & Access & Consumption & Knowledge/ Attitudes/ Awareness & General health measures & Harms \\
\hline Class series & 14 & 172 & 107 & 35 & 2 \\
\hline Community-wide intervention & 9 & 31 & 16 & 14 & 0 \\
\hline Comprehensive school health & 4 & 17 & 16 & 6 & 0 \\
\hline Group discussion & 6 & 43 & 29 & 13 & 0 \\
\hline Individual counseling/ teaching & 3 & 32 & 16 & 9 & 0 \\
\hline Interactive approach & 25 & 166 & 100 & 52 & 1 \\
\hline Parent involvement & 16 & 105 & 63 & 34 & 1 \\
\hline Pedagogical/ lecture approach & 2 & 28 & 14 & 10 & 0 \\
\hline Peer-led & 2 & 19 & 16 & 5 & 0 \\
\hline Community garden & 4 & 19 & 13 & 2 & 0 \\
\hline Policy & 16 & 37 & 15 & 8 & 1 \\
\hline Marketing & 14 & 51 & 31 & 15 & 1 \\
\hline Educational written material & 19 & 127 & 76 & 36 & 2 \\
\hline Behavior modification & 8 & 67 & 38 & 23 & 1 \\
\hline Creating supportive environments & 15 & 79 & 49 & 27 & 0 \\
\hline Provision of fruit and/or vegetables & 23 & 116 & 64 & 20 & 2 \\
\hline Other & 32 & 144 & 76 & 32 & 2 \\
\hline
\end{tabular}


Table 5 Intervention delivery and outcomes

\begin{tabular}{|c|c|c|c|c|c|}
\hline Intervention delivered by & Access & Consumption & $\begin{array}{c}\text { Knowledge/ Attitudes/ } \\
\text { Awareness }\end{array}$ & $\begin{array}{c}\text { General health } \\
\text { measures }\end{array}$ & Harms \\
\hline Teacher & 14 & 130 & 85 & 31 & 3 \\
\hline Principal/school administration & 9 & 30 & 14 & 6 & 1 \\
\hline Community lay person & 3 & 15 & 11 & 4 & 0 \\
\hline Peer & 1 & 17 & 15 & 4 & 0 \\
\hline Farmer & 0 & 2 & 2 & 0 & 0 \\
\hline Dietician & 2 & 18 & 8 & 7 & 0 \\
\hline Other health professional & 2 & 23 & 10 & 8 & 0 \\
\hline Other school personnel & 10 & 49 & 29 & 9 & 2 \\
\hline Health department or Ministry of Health & 3 & 11 & 3 & 2 & 0 \\
\hline Other & 29 & 148 & 80 & 37 & 1 \\
\hline
\end{tabular}

personnel [224,264,307]; peers plus teachers and/or administrators [16,30,35,40,55,143,155,190]; administrators and other school personnel [193,297,305]; peers plus other school personnel $[55,160]$; peers plus administrators plus other school personnel [173]; peers plus dietician $[187,277]$; peers plus community members [124]; dietician plus other school or health professionals [19,115,250,318]; and other school or health professionals plus other community or health providers $[191,230,286]$.

\section{Knowledge syntheses summary}

This scoping review identified 30 systematic reviews, all of which reported on consumption outcomes; only eight reported on access outcomes as well. Approximately two-thirds reported on our secondary outcomes of interest that included knowledge, attitudes, awareness, and general health measures. None of the included systematic reviews reported on harms.

\section{Discussion}

The Cochrane Public Health Group acknowledges that a scoping review is a critical step in defining a systematic review question [347]. We identified a large volume of interventional research found within peer-reviewed and grey literature associated with FV access and consumption. Using a scoping review process [347], we categorized these studies with respect to outcomes based on a number of parameters such as study design, target audience, intervention location, intervention strategy, and intervention deliverer.

The predominant outcome measure was consumption. In comparison, harm was included as an outcome measure in an extremely small number of studies, which may indicate that there are few risks or potential harms associated with interventions used to increase FV consumption. It also possible that harms were overlooked given that few of these studies evaluated interventions implemented in low- or middle-income countries where populations could be more vulnerable. The bias of studies toward high-income countries and not low- and middleincome countries warrants further investigation as intervention effectiveness may vary across these populations.

While consumption measures were commonly reported, this review identified a small yet important subset of literature examining the effectiveness of interventions that increase access to $\mathrm{FV}$. We believe this to be a relatively overlooked but critically important issue since consumption of $\mathrm{FV}$ is contingent upon access to them. A number of articles discussed FV accessibility; however, many of these studies lacked before-after comparison data or other comparison groups. These studies were excluded during full text relevance screening since they did not evaluate the impact of an intervention or policy. Specific measures of access were lacking in included studies; authors often identified a goal of evaluating the impact of interventions or policies to increase $\mathrm{FV}$ access but measured changes in consumption behaviors as a proxy for access.

Measuring FV access seems to be further complicated by a lack of consistent, meaningful, validated instruments; across the studies there was great variability in the ways access was measured. While some studies evaluated the impact of policy change on FV access and consumption, very few looked at population level initiatives or reported on population subgroups to be able to evaluate their impact on children aged five to 18 years. Further, despite the potential benefits of increasing access to FV, only a small number of studies partnered with farms or involved establishing community gardens. We also did not find any studies that evaluated changes in food supply or market inventory, two additional factors that influence access to and consequently consumption of FV.

This review has several methodological and operational limitations. A number of studies that examined knowledge, attitudes, awareness, and general health measures were excluded if they did not also examine either of our primary outcomes of access or consumption. 
It is possible, that relevant studies that explored our secondary outcomes were missed as a result of these methodological considerations. Operationally, the included studies were limited by the language fluency of the reviewers. Five articles published in Spanish were reviewed and included through titles and abstracts and full text phases, however because the Spanish-speaking reviewers were not available at the data extraction stage we excluded these papers. Data extraction was limited to studies published in English or French. Finally, including participants older than 18 years would have broadened the scope of available literature but the number of studies would not have been manageable for this scoping review. Therefore, the findings of this review are limited to children aged five to 18 years.

\section{Conclusions}

This scoping review sought to identify and map literature that has evaluated the effects of community-based interventions designed to increase FV access and/or consumption among five to 18-year olds. A variety of interventions have been used to support and increase FV consumption. Schools were the most common location for interventions, which were typically multi-faceted, targeted at individuals less than 15 years of age, and delivered by teachers or other school personnel. Additional research on implementing interventions in low- and middle-income countries is warranted based on the limited literature focusing on those populations. Finally, a somewhat narrow field of literature was identified with respect to FV access, suggesting that future research examining interventions to increase FV consumption should include direct outcome measures of FV access. Previously published syntheses revealed a gap in our understanding of the effectiveness of interventions that increase access to FV, since no syntheses that examined access to fruit and vegetables among children were found through our comprehensive literature search. While this scoping review identified several knowledge synthesis products, all were focused on FV consumption. Since consumption is contingent upon access, a focused systematic review that examines these interventions is needed. Such a review should examine and synthesize literature that seeks to increase access through interventions including (but not limited to): influencing FV supply, changing food environments, and enhancing FV sales in cafeterias and grocery stores.

\section{Additional files}

Additional file 1: Search strategy.

Additional file 2: Details of included studies.

\section{Competing interests}

The authors declare that they have no competing interests.

\section{Authors' contributions}

RG participated in the conception and methodological design of this review, participated in searching and reviewing studies, and drafted the manuscript. DFL, DC, and LP participated in the conception and methodological design of this review, participated in searching and reviewing, and revised the manuscript. All authors read and approved the final manuscript.

\section{Acknowledgements}

We wish to thank the Fruit and Vegetable Access and Consumption Review Study Team, Rachel Warren, and Sharon Peck-Reid for their assistance in completing this scoping review.

Received: 22 December 2011 Accepted: 23 August 2012

Published: 30 August 2012

\section{References}

1. World Health Organization: Global Strategy on Diet, Physical Activity. Geneva, Switzerland: World Health Organization; 2004.

2. U.S. Department of Health and Human Services and U.S. Department of Agriculture: Dietary Guidelines for Americans. Washington, DC: U.S. Government Printing Office; 2005.

3. Lien N, Lytle LA, Klepp Kl: Stability in consumption of fruit, vegetables, and sugary foods in a cohort from age 14 to age 21. Prev Med 2001, 33(3):217-226.

4. Lytle LA, Kubik MY: Nutritional issues for adolescents. Best Pract Res Clin Endocrinol Metab 2003, 17(2):177-189.

5. Kelder SH, Perry CL, Klepp Kl, Lytle LL: Longitudinal tracking of adolescent smoking, physical activity, and food choice behaviors. Am J Public Health 1994, 84(7):1121-1126.

6. Kvaavik E, Andersen LF, Klepp Kl: The stability of soft drinks intake from adolescence to adult age and the association between long-term consumption of soft drinks and lifestyle factors and body weight. Public Health Nutr 2005, 8(2):149-157.

7. Lock K, Pomerleau J, Causer L, Altmann DR, McKee M: The global burden of disease attributable to low consumption of fruit and vegetables: implications for the global strategy on diet. Bull World Health Organ 2005, 83(2):100-108.

8. Krolner R, Rasmussen M, Brug J, Knut-Inge K, Wind M, Due P: Determinants of fruit and vegetable consumption among children and adolescents: a review of the literature. Part II: qualitative studies. Int J Behav Nutr Phys Act 2011, 8(1):112.

9. Blanchette $L$, Brug J: Determinants of fruit and vegetable consumption among 6-12-year-old children and effective interventions to increase consumption. J Hum Nutr Diet 2005, 18(6):431-443.

10. Bodor JN, Rose D, Farley TA, Swalm C, Scott SK: Neighbourhood fruit and vegetable availability and consumption: the role of small food stores in an urban environment. Public Health Nutr 2007, 11(4):413-420.

11. Rasmussen M, Krolner R, Klepp KI, Lytle L, Brug J, Bere E, Due P: Determinants of fruit and vegetable consumption among children and adolescents: a review of the literature. Part I: quantitative studies. $J$ Behav Nutr Phys Act 2006, 3(22): (Epublication).

12. Ball K, Crawford D, Mishra G: Socio-economic inequalities in women's fruit and vegetable intakes: a multilevel study of individual, social and environmental mediators. Public Health Nutr 2006, 9(5):623-630.

13. Kristjansdottir AG, Thorsdottir I, De Bourdeaudhuij I, Due P, Wind M, Klepp Kl: Determinants of fruit and vegetable intake among 11-year-old schoolchildren in a country of traditionally low fruit and vegetable consumption. Int J Behav Nutr Phys Act 2006, 3:41.

14. Ciliska D, Miles E, O'Brien MA, Turl C, Tomasik HH, Donovan U, Beyers J: Effectiveness of community-based interventions to increase fruit and vegetable consumption. J Nutr Educ 2000, 32(6):341-352.

15. de Sa J, Lock K: School-based Fruit and Vegetable Schemes: A review of the Evidence. UK: Department of Public Health and Policy, London School of Hygiene and Tropical Medicine London; 2007:1-39.

16. Delgado-Noguera M, Tort S, Martinez-Zapata MJ, Bonfill X: Primary school interventions to promote fruit and vegetable consumption: a systematic review and meta-analysis. Prev Med 2011, 53(1-2):3-9.

17. Wolfenden L, Wyse RJ, Britton BI, Campbell KJ, Hodder RK, Stacey FG, McElduff $P$, James EL: Interventions for increasing fruit and vegetable consumption in preschool aged children (Protocol). Cochrane Database Syst Rev 2010, Issue 6. Art. No.: CD008552. 
18. Ammerman A, Lindquist C, I. Research Triangle, C. Research Triangle InstituteUniversity of North Carolina Evidence-based Practice, S. United, R. Agency for Healthcare, and Quality: The efficacy of interventions to modify dietary behavior related to cancer risk. In Evidence report/Technology Assessment AHRQ Publication. Vol. no. 25. Edited by. Rockville: Agency for Healthcare Research and Quality, U.S. Dept. of Health and Human Services; 2001.

19. Ammerman AS, Lindquist $\mathrm{CH}$, Lohr KN, Hersey J: The efficacy of behavioral interventions to modify dietary fat and fruit and vegetable intake: a review of the evidence. Prev Med 2002, 35(1):25-41.

20. Berti PR, Krasevec J, FitzGerald S: A review of the effectiveness of agriculture interventions in improving nutrition outcomes. Public Health Nutr 2004, 7:599-609.

21. Burchett $\mathrm{H}$ : Increasing fruit and vegetable consumption among British primary schoolchildren: a reivew. Heal Educ 2003, 103(2):99-109.

22. Campbell $\mathrm{K}$, Waters $\mathrm{E}, \mathrm{O}$ 'Meara $\mathrm{S}$, Summerbell $\mathrm{C}$ : Interventions for preventing obesity in childhood. A systematic review. Obes Rev 2001, 2(3):149-157.

23. French SA, Stables G: Environmental interventions to promote vegetable and fruit consumption among youth in school settings. Prev Med 2003, 37(6 part 1):593-610

24. Hastings G, Stead M, McDermott L, Forsyth A, MacKintosh A, Rayner M: Review of Research on the Effects of Food Promotion to Children. Glasgow, Scotland: Food Standards Agency by the Centre for Social Marketing, the University of Strathclyde; 2003.

25. Hingle MD, O'Connor TM, Dave JM, Baranowski T: Parental involvement in interventions to improve child dietary intake: a systematic review. Prev Med 2010, 51(2):103-111.

26. Howerton MW, Bell BS, Dodd KW, Berrigan D, Stolzenberg-Solomon R, Nebeling L: School-based nutrition programs produced a moderate increase in fruit and vegetable consumption: Meta and pooling analyses from 7 studies. J Nutr Educ Behav 2007, 39(4):186-196.

27. Jago R, Baranowski T, Baranowski JC: Fruit and vegetable availability: a micro environmental mediating variable? Public Health Nutr 2007, 10 (7):681-689

28. Jaime PC, Lock K: Do school based food and nutrition policies improve diet and reduce obesity? Prev Med 2009, 48(1):45-53.

29. Jepson R, Harris F, MacGillivray S, Kearney N, Rowa-Dewar N: A review of the Effectiveness of Interventions, Approaches and Models at Individual, Community and Population Level that are Aimed at Changing Health Outcomes Through Changing Knowledge Attitudes and Behaviour. London: NICE (National Institute for Health and Clinical Excellence); 2006:1-218.

30. Knai C, Pomerleau J, Lock K, McKee M: Getting children to eat more fruit and vegetables: a systematic review. Prev Med 2006, 42(2):85-95.

31. Kremers SPJ, de Bruijn GJ, Droomers M, van Lenthe F, Brug J: Moderators of environmental intervention effects on diet and activity in youth. Am J Prev Med 2007, 32(2):163-172

32. Lissau I: Prevention of overweight in the school arena. Acta Paediatrica 2007, 96(Supplement 454):12-18.

33. McArthur DB: Heart healthy eating behaviors of children following a school-based intervention: a meta-analysis. Issues Compr Pediatric Nurs 1998, 21(1):35-48.

34. Oldroyd J, Burns C, Lucas P, Haikerwal A, Waters E: The effectiveness of nutrition interventions on dietary outcomes by relative social disadvantage: a systematic review. J Epidemiol Community Health 2008 62(7):573-579.

35. Perez-Escamilla R, Hromi-Fiedler A, Vega-Lopez S, Bermudez-Millan A, Segura-Perez S: Impact of peer nutrition education on dietary behaviors and health outcomes among Latinos: a systematic literature review. J Nutr Educ Behav 2008, 40(4):208-225.

36. Pomerleau J, Lock K, Knai C, McKee M: Effectiveness of Interventions and Programmes Promoting Fruit and Vegetable Intake in Individuals of all Ages. Geneva, Switzerland: World Health Organization; 2005:1-133.

37. Robinson-O'Brien R, Story M, Heim S: Impact of garden-based youth nutrition intervention programs: a review. J Am Diet Assoc 2009, 109(2):273-280.

38. Roe L, Hunt $\mathrm{P}$, Bradshaw $\mathrm{H}$, Rayner M: Health promotion interventions to promote healthy eating in the general population: a review. Health Promot Eff Rev 1997, 6:198.

39. Sahay TB, Ashbury FD, Roberts M, Rootman I: Effective components for nutrition interventions: a review and application of the literature. Heal Promot Pract 2006, 7(4):418-427.
40. Shepherd J, Harden A, Rees R, Brunton G, Garcia J, Oliver S, Oakley A: Young people and healthy eating: a systematic review of research on barriers and facilitators. Heal Educ Res 2006, 21(2):239-257.

41. Summerbell CD, Waters E, Edmunds LD, Kelly S, Brown T, Campbell KJ: Interventions for preventing obesity in children. Cochrane Database Syst Rev 2005, (3):CD001871.

42. Thomas H, Ciliska D, Micucci S, Wilson-Abra J, Dobbins M: Effectiveness of Physical Activity Enhancement and Obesity Prevention Program in Children and Youth. Hamilton: Effective Public Health Practice Project; 2004.

43. Van Cauwenberghe E, Maes L, Spittaels H, van Lenthe FJ, Brug J, Oppert JM, De Bourdeaudhuij I: Effectiveness of school-based interventions in Europe to promote healthy nutrition in children and adolescents: systematic review of published and 'grey' literature. Br J Nutr 2010, 103(6):781-797.

44. Wall J, Mhurchu CN, Blakely T, Rodgers A, Wilton J: Effectiveness of monetary incentives in modifying dietary behavior: a review of randomized, controlled trials. Nutr Rev 2006, 64(12):518-531.

45. Baranowski T, Baranowski J, Thompson D, Buday R, Jago R, Griffith MJ, Islam $\mathrm{N}$, Nguyen N, Watson KB: Video game play, child diet, and physical activity behavior change: a randomized clinical trial. Am J Prev Med 2011, 40(1):33-38.

46. Baranowski T, Baranowski JC, Cullen KW, Thompson DI, Nicklas T, Zakeri IF, Rochon J: The Fun, Food, and Fitness Project (FFFP): The Baylor GEMS pilot study. Ethnicity \& Disease 2003, 13(1 SUPPL. 1):S30-S39.

47. Beech BM, Klesges RC, Kumanyika SK, Murray DM, Klesges L, McClanahan B, Slawson D, Nunnally C, Rochon J, McLain-Allen B, Pree-Cary J: Child- and parent-targeted interventions: the Memphis GEMS pilot study. Ethnicity \& Disease 2003, 13(1 Suppl 1):S40-S53.

48. Chen JL, Weiss S, Heyman MB, Cooper B, Lustig RH: The efficacy of the web-based childhood obesity prevention program in chinese american adolescents (web abc study). J Adolesc Heal 2011, 49(2):148-154.

49. DeBar LL, Ritenbaugh C, Aickin M, Orwoll E, Elliot D, Dickerson J, Vuckovic N, Stevens VJ, Moe E, Irving LM: Youth: a health plan-based lifestyle intervention increases bone mineral density in adolescent girls. Archives of Pediatrics \& Adolescent Medicine 2006, 160(12):1269-1276.

50. Epstein LH, Gordy CC, Raynor HA, Beddome M, Kilanowski CK, Paluch R: Increasing fruit and vegetable intake and decreasing fat and sugar intake in families at risk for childhood obesity. Obes Res 2001, 9(3):171-178.

51. Faith MS, Rose E, Matz PE, Pietrobelli A, Epstein LH: Co-twin control designs for testing behavioral economic theories of child nutrition: methodological note. Int J Obes 2006, 30(10):1501-1505.

52. Francis M, Nichols SSD, Dalrymple N: The effects of a school-based intervention programme on dietary intakes and physical activity among primary-school children in Trinidad and Tobago. Public Health Nutrition 2010, 13(5):738-747.

53. Fulkerson JA, Rydell S, Kubik MY, Lytle L, Boutelle K, Story M, NeumarkSztainer D, Dudovitz B, Garwick A: Healthy home offerings via the mealtime environment (HOME): feasibility, acceptability, and outcomes of a pilot study. Obesity 2010, 18(SUPPL. 1):S69-S74.

54. Gratton L, Povey R, Clark-Carter D: Promoting children's fruit and vegetable consumption: interventions using the Theory of Planned Behaviour as a framework. Br J Heal Psychol 2007, 12(4):639-650.

55. Hendy HM, Williams KE, Camise TS: "Kids Choice" school lunch program increases children's fruit and vegetable acceptance. Appetite 2005, 45:250-263.

56. Jaime PC, Machado FM, Westphal MF, Monteiro CA: Nutritional education and fruit and vegetable intake: a randomized community trial. Revista De saude Publica 2007, 41(1):154-157.

57. Johnston CA, Palcic JL, Tyler C, Stansberry S, Reeves RS, Foreyt JP: Increasing vegetable intake in mexican-american youth: a randomized controlled trial. J Am Diet Assoc 2011, 111(5):716-720.

58. LaPorte MR, Gibbons CC, Cross E: The effects of a cancer nutrition education program on sixth grade students. School Food Service Research Review 1989, 13(2):124-129.

59. Lubans DR, Morgan PJ, Callister R, Collins CE: Effects of integrating pedometers, parental materials, and E-mail support within an extracurricular school sport intervention. J Adolesc Heal 2009, 44(2):176-183.

60. McKenzie J, Dixon LB, Smiciklas-Wright H, Mitchell D, Shannon B, Tershakovec $A$ : Change in nutrient intakes, number of servings, and contributions of total fat from food groups in 4- to 10-year-old children enrolled in a nutrition education study. J Am Diet Assoc 1996, 96:865-873. 
61. Mihas C, Mariolis A, Manios Y, Naska A, Arapaki A, Mariolis-Sapsakos T, Tountas $Y$ : Evaluation of a nutrition intervention in adolescents of an urban area in Greece: short- and long-term effects of the VYRONAS study. Public Health Nutrition 2010, 13(5):712-719.

62. Patrick K, Calfas KJ, Norman GJ, Zabinski MF, Sallis JF, Rupp J, Covin J, Cella $\mathrm{J}$ : Randomized controlled trial of a primary care and home-based intervention for physical activity and nutrition behaviors: PACE + for adolescents. Archives of Pediatrics and Adolescent Medicine 2006, 160(2):128-136.

63. Patrick K, Sallis JF, Prochaska JJ, Lydston DD, Calfas KJ, Zabinski MF, Wilfley $D E$, Saelens BE, Brown DR: A multicomponent program for nutrition and physical activity change in primary care: PACE + for adolescents. Archives of Pediatrics \& Adolescent Medicine 2001, 155(8):940-946.

64. Pearson N, Atkin AJ, Biddle SJ, Gorely T: A family-based intervention to increase fruit and vegetable consumption in adolescents: a pilot study. Public Health Nutrition 2010, 13(6):876-885.

65. Queral C: The impact of a Nutrition Education Program on Nutrition Knowledge and Attitudes, as well as Food Selection, in a Cohort of Migrant and Seasonal Farm Worker Children. United States: Touro University International; 2007:285.

66. Rosenberg DE, Norman GJ, Sallis JF, Calfas KJ, Patrick K: Covariation of adolescent physical activity and dietary behaviors over 12 months. J Adolesc Heal 2007, 41(5):472-478.

67. Story M, Sherwood NE, Himes JH, Davis M, Jacobs DR Jr, Cartwright $Y$, Smyth M, Rochon J: An after-school obesity prevention program for African-American girls: the Minnesota GEMS pilot study. Ethn Dis 2003, 13(1 Suppl 1):S54-S64

68. Talvia S, Rasanen L, Lagstrom H, Pahkala K, Viikari J, Ronnemaa T, Arffman M, Simell O: Longitudinal trends in consumption of vegetables and fruit in Finnish children in an atherosclerosis prevention study (STRIP). Eur J Clin Nutr 2006, 60(2):172-180

69. Wardle J, Cooke LJ, Gibson EL, Sapochnik M, Sheiham A, Lawson M: Increasing children's acceptance of vegetables; a randomized trial of parent-led exposure. Appetite 2003, 40(2):155-162

70. Warren JM, Henry CJK, Lightowler HJ, Bradshaw SM, Perwaiz S: Evaluation of a pilot school programme aimed at the prevention of obesity in children. Heal Promot Int 2003, 18(4):287-296.

71. Werch C, Bian H, Carlson J, Moore M, DiClemente C, Huang I, Ames S, Thombs D, Weiler R, Pokorny S: Brief integrative multiple behavior intervention effects and mediators for adolescents. J Behav Med 2011, 34(1):3-12.

72. Auld GW, Romaniello C, Heimendinger J, Hambidge C, Hambidge M: Outcomes from a school-based nutrition education program using resource teachers and cross-disciplinary models - Duplicate of Ref ID 90062. J Nutr Educ 1998, 30(5):268-280.

73. Bates NJ: An Evaluation of a Stage of Change Nutrition Intervention in Latino Families with Young Children. United States: University of Illinois at Chicago, Health Sciences Center, School of Public Health; 2001:353.

74. Bell CG, Lamb MW: Nutrition education and dietary behavior of fifth graders. J Nutr Educ 1973, 5:196-199.

75. Boaz A, Ziebland S, Wyke S, Walker J: A 'five-a-day' fruit and vegetable pack for primary school children. Part II: controlled evaluation in two Scottish schools. Heal Educ J 1998, 57(2):105-116.

76. Cade J, Lambert $\mathrm{H}$ : Evaluation of the effect of the removal of the family income supplement (FIS) free school meal on the food intake of secondary schoolchildren. J Public Health Med 1991, 13(4):295-306

77. Casazza K: A Computer Based Approach to Improve the Dietary and Physical Activity Patterns of a Diverse Group of Adolescents. United States: Florida International University; 2006:221.

78. Craven K, Moore J, Swart A, Keene A, Kolasa K: School-based nutrition education intervention: effect on achieving a healthy weight among overweight ninth-grade students. J Public Health Manag Pract JPHMP 2011 17(2):141-146.

79. Covelli MM: Efficacy of a School-Based Intervention on Blood Pressure and Cortisol Levels of African American Adolescents. In PhD thesis. Gainesville, FL: University of Florida; 2000:129.

80. Cullen KW, Watson K, Baranowski T, Baranowski JH, Zakeri I: Squire's quest: intervention changes occurred at lunch and snack meals. Appetite 2005, 45(2):148-151.
81. Cullen KW, Zakeri I: Fruits, vegetables, milk, and sweetened beverages consumption and access to a la carte/snack bar meals at school. Am J Public Health 2004, 94(3):463-467.

82. Cummins S, Petticrew M, Higgins C, Findlay A, Sparks L: Large scale food retailing as an intervention for diet and health: quasi-experimental evaluation of a natural experiment. J Epidemiol Community Health 2005, 59(12):1035-1040.

83. Day LL, Rodriguez EC: Impact of a field trip to a health museum on children's health-related behaviors and perceived control over illness. Am J Heal Educ 2002, 33(2):94-100.

84. Di Noia J, Contento IR, Prochaska JO: Computer-mediated intervention tailored on transtheoretical model stages and processes of change increases fruit and vegetable consumption among urban AfricanAmerican adolescents. Am J Health Promot AJHP 2008, 22(5):336-341.

85. Edwards CS, Hermann JR: Piloting a cooperative extension service nutrition education program on first-grade children's willingness to try foods containing legumes. J Ext 2011, 49(1):Article 1IAW3 (Epublication).

86. Eriksen $\mathrm{K}$, HaraldsdC ${ }^{3}$ ttir J, Pederson R, Flyger HV: Effect of a fruit and vegetable subscription in Danish schools. Public Health Nutr 2003, 6(1):57-63.

87. Fahlman MM, Dake JA, McCaughtry N, Martin J: A pilot study to examine the effects of a nutrition intervention on nutrition knowledge, behaviors, and efficacy expectations in middle school children. J Sch Heal 2008, 78 (4):216-222.

88. Foerster SB, Gregson J, Beall DL, Hudes M, Magnuson H, Livingston S, Davis MA, Joy ABJ, Garbolino T: The California children's 5 a Day Power Play! Campaign: evaluation of a large-scale social marketing initiative. Fam Commun Health 1998, 21(1):46-64.

89. Friel S, Kelleher C, Campbell P, Nolan G: Evaluation of the Nutrition Education at Primary School (NEAPS) programme. Public Health Nutr 1999, 2(4):549-555.

90. Georgiou C: The Effect of Nutrition Education on Third Graders' School Lunch Consumption in a School Offering Food Pyramid Choice Menus. Oregon: Oregon State Department of Education, Salem.Child Nutrition Division; 1998.

91. Gortmaker SL, Cheung LWY, Peterson KE, Chomitz G, Cradle JH, Dart H, Fox MK, Bullock RB, Sobol AM, Colditz G, Field AE, Laird N: Impact of a schoolbased interdisciplinary intervention on diet and physical activity among urban primary school children: eat well and keep moving. Arch Pediatr Adolesc Med 1999, 153(9):975-983.

92. Gosliner WA, James P, Yancey AK, Ritchie L, Studer N, Crawford PB: Impact of a worksite wellness program on the nutrition and physical activity environment of child care centers. Am J Health Promot AJHP 2010, 24(3):186-189

93. Gribble LS, Falciglia G, Davis AM, Couch SC: A curriculum based on social learning theory emphasizing fruit exposure and positive parent childfeeding strategies: a pilot study. J Am Diet Assoc 2003, 103(1):100-103.

94. Hendy HM, Williams KE, Camise TS: Kid's Choice Program improves weight management behaviors and weight status in school children. Appetite 2011, 56(2):484-494.

95. Hoddinott J, Wiesmann D: In The Impact of Conditional cash Transfer Programs on Food Consumption in Honduras, Mexico, and Nicaragua. Edited by Adato M, Hoddinott J. Washington, DC: International Food Policy Research Institute; 2010.

96. Hollar D, Messiah SE, Lopez-Mitnik G, Hollar TL, Almon M, Agatston AS: Healthier options for public schoolchildren program improves weight and blood pressure in 6- to 13-year-olds. J Am Diet Assoc 2010, 110(2):261-267.

97. Horne PJ, Tapper K, Lowe CF, Hardman CA, Jackson MC, Woolner J: Increasing children's fruit and vegetable consumption: a peer-modelling and rewards-based intervention. Eur J Clin Nutr 2004, 58(12):1649-1660.

98. Jacob T: Evaluation of Food and Fun for Everyone: A Nutrition Education Program for Third and Fourth Grade Students. United States: Oklahoma State University; 2009:80.

99. Jamelske E, Bica LA, McCarty DJ, Meinen A: Preliminary findings from an evaluation of the USDA fresh fruit and vegetable program in Wisconsin schools. Wis Med J 2008, 107(5):225-230.

100. Jimenez MM, Receveur O, Trifonopoulos M, Kuhnlein H, Paradis G, Macaulay AC: Comparison of the dietary intakes of two different groups of children (grades 4 to 6 ) before and after the Kahnawake Schools Diabetes Prevention Project. J Am Diet Assoc 2003, 103(9):1191-1194. 
101. Kelder S, Hoelscher DM, Barroso CS, Walker JL, Cribb P, Hu S: The CATCH Kids Club: a pilot after-school study for improving elementary students' nutrition and physical activity. Public Health Nutr 2005, 8(2):133-140.

102. Liquori T, Koch PD, Contento IR, Castle J: The cookshop program: outcome evaluation of a nutrition education program linking lunchroom food experiences with classroom cooking experiences. J Nutr Educ 1998, 30(5):302-313.

103. Long JD: The Effects of a School-Based Nutrition Education Intervention on self-efficacy for Healthy Eating, Usual Food Choices, Dietary Knowledge, and Fruit, Vegetable, and Fat Consumption in Adolescents. In PhD thesis. San Antonio, TX: University of Texas Health Science Center; 2001:202.

104. Long JD, Stevens KR: Using technology to promote self-efficacy for healthy eating in adolescents. J Nurs Scholarsh Off Pub/ Sigma Theta Tau Int Honor Soc Nurs Sigma Theta Tau 2004, 36(2):134-139.

105. Manios Y, Moschandreas J, Hatzis C, Kafatos A: Health and nutrition education in primary schools of Crete: changes in chronic disease risk factors following a 6-year intervention programme. B J Nutr 2002, 88:315-324

106. Matvienko O: Impact of a nutrition education curriculum on snack choices of children ages six and seven years. J Nutr Educ Behav 2007, 39(5):281-285.

107. McAleese JD, Rankin LL: Garden-based nutrition education affects fruit and vegetable consumption in sixth-grade adolescents. J Am Diet Assoc 2007, 107(4):662-665.

108. Morgan PJ, Warren JM, Lubans DR, Saunders KL, Quick Gl, Collins CE: The impact of nutrition education with and without a school garden on knowledge, vegetable intake and preferences and quality of school life among primary-school students. Public Health Nutr 2010, 13(11):1931-1940.

109. Olvera N, Bush JA, Sharma SV, Knox B, Scherer RL, Butte NF: BOUNCE: a community-based mother-daughter healthy lifestyle intervention for low-income Latino families. Obesity 2010, 18(Suppl 1):S102-S104.

110. Perry CL, Zauner M, Oakes JM, Taylor G, Bishop DB: Evaluation of a theater production about eating behavior of children. J Sch Heal 2002, 72(6):256-261

111. Raghunatha Rao D, Vijayapushpam T, Subba Rao GM, Antony GM, Sarma KVR: Dietary habits and effect of two different educational tools on nutrition knowledge of school going adolescent girls in Hyderabad India. Eur J Clin Nutr 2007, 61(9):1081-1085.

112. Ratcliffe MM, Merrigan KA, Rogers BL, Goldberg JP: The effects of school garden experiences on middle school-aged students' knowledge, attitudes, and behaviors associated with vegetable consumption. Heal Promot Pract 2011, 12(1):36-43.

113. Russ CR, Tate DF, Whiteley JA, Winett RA, Winett SG, Pfleger J: The effects of an innovative WWW-based health behavior program on the nutritional practices of tenth grade girls: preliminary report on the Eat4Life Program. J Gend Cult Heal 1998, 3(2):121-128.

114. Schagen S, Blenkinsop S, Schagen I, Scott E, Teeman D, White G, Ransley J, Cade J, Greenwood D: In Evaluation of the School Fruit and Vegetable Pilot Scheme: final report. Edited by R. National Foundation for Educational. Big Lottery Fund: University of Leeds; 2005.

115. Schwartz MB: The influence of a verbal prompt on school lunch fruit consumption: A pilot study. Int J Behav Nutr Phys Act 2007, 4(6): (Epublication).

116. Schwartz RP, Hamre R, Dietz WH, Wasserman RC, Slora EJ, Myers EF, Sullivan S, Rockett H, Thoma KA, Dumitru G, Resnicow KA: Office-based motivational interviewing to prevent childhood obesity - A feasibility study. Arch Pediat Adolesc Med 2007, 161(5):495-501.

117. Shannon B, Graves K, Hart M: Food behavior of elementary school students after receiving nutrition education. J Am Diet Assoc 1982, 81 (4):428-434

118. Simons-Morton BG, Parcel GS, Baranowski T, Forthofer R, O'Hara NM: Promoting physical activity and a healthful diet among children: results of a school-based intervention study. Am J Public Health 1991, 81(8):986-991.

119. Singhal N, Misra A, Shah P, Gulati S: Effects of controlled school-based multi-component model of nutrition and lifestyle interventions on behavior modification, anthropometry and metabolic risk profile of urban Asian Indian adolescents in North India. Eur J Clin Nutr 2010, 64(4):364-373

120. Tanner A, Duhe S, Evans A, Condrasky M: Using student-produced media to promote healthy eating - A pilot study on the effects of a media and nutrition intervention. Sci Commun 2008, 30(1):108-125.
121. Tak NI, te Velde SJ, Brug J: Long-term effects of the Dutch Schoolgruiten Project-promoting fruit and vegetable consumption among primaryschool children. Public Health Nutr 2009, 12(8):1213-1223.

122. Vargas ICDS, Sichieri R, Sandre-Pereira G, da Veiga GV: Evaluation of an obesity prevention program in adolescents of public schools. Rev Saude Publica 2011, 45(1):59-68.

123. Wagner JL: The Relationship of Parent and Child Food Choices: Influences of a Supermarket Intervention. United States: Virginia Polytechnic Institute and State University; 1991:179.

124. Walsh CM, Dannhauser A, Joubert G: Impact of a nutrition education programme on nutrition knowledge and dietary practices of lower socioeconomic communities in the Free State and Northern Cape. South Afr J Clin Nutr 2003, 16(3):89-95.

125. White G: Evaluation of the school fruit and vegetable pilot scheme. Educ Heal 2006, 24(4):62-64

126. Williams JE: Social Support and Adolescent Nutrition Behaviors in AfricanAmerican Families. United States: University of South Carolina; 2004:188.

127. Agozzino E, Esposito D, Genovese S, Manzi E, Russo Krauss P: Evaluation of the effectiveness of a nutrition education intervention performed by primary school teachers. Ital J Public Health 2007, 4(4):131-137.

128. Al Ashfield-Watt $P$, Stewart EA, Scheffer JA: A pilot study of the effect of providing daily free fruit to primary-school children in Auckland, New Zealand. Public Health Nutr 2009, 12(5):693-701.

129. Amaro S, Viggiano A, Di Costanzo A, Madeo I, Baccari ME, Marchitelli E, Raia M, Viggiano E, Deepak S, Monda M, De Luca B: Kaledo, a new educational board-game, gives nutritional rudiments and encourages healthy eating in children: a pilot cluster randomized trial. Eur J Pediatr 2006, 165(9):630-635.

130. Anderson A, Hetherington M, Adamson A, Porteous LEG, Higgins C, Foster $\mathrm{E}$ : The Development and Evaluation of a Novel School Based Intervention to Increase Fruit and Vegetable Intake in Children. London: Food Standards Agency; 2000.

131. Anderson AS, Porteous LE, Foster E, Higgins C, Stead M, Hetherington M, Ha MA, Adamson AJ: The impact of a school-based nutrition education intervention on dietary intake and cognitive and attitudinal variables relating to fruits and vegetables. Public Health Nutr 2005, 8(6):650-656.

132. Angelopoulos PD, Milionis HJ, Grammatikaki E, Moschonis G, Manios Y: Changes in $\mathrm{BMI}$ and blood pressure after a school based intervention: the CHILDREN study. Eur J Public Health 2009, 19(3):319-325.

133. Ask AS, Hernes S, Aarek I, Vik F, Brodahl C, Haugen M: Serving of free school lunch to secondary-school pupils - a pilot study with health implications. Public Health Nutr 2010, 13(2):238-244.

134. Auld GW, Romaniello C, Heimendinger J, Hambidge C, Hambidge M: Outcomes from a school-based nutrition education program alternating special resource teachers and classroom teachers. J Sch Heal 1999, 69(10):403-408.

135. Baranowski T, Baranowski J, Cullen KW, DeMoor C, Rittenberry L, Hebert D: 5 a day achievement badge for African-American Boy Scouts: pilot outcome results. Prev Med 2002, 34(3):353-363.

136. Baranowski T, Baranowski J, Cullen KW, Marsh T, Islam N, Zakeri I, HonessMorreale L, DeMoor C: Squire's Quest! Dietary outcome evaluation of a multimedia game. Am J Prev Med 2003, 24(1):52-61.

137. Baranowski T, Davis M, Resnicow K, Baranowski J, Doyle C, Lin LS, Smith M, Wang DT: Gimme 5 fruit, juice, and vegetables for fun and health: outcome evaluation. Health Educ Behav Off Publ Soc Public Health Educ 2000, 27(1):96-111.

138. Bates HM: Promoting Healthy Eating and Active Living in Schools: A Pilot Study. Canada: University of Alberta; 2010:213.

139. Bere E: Fruits and Vegetables make the Mark. Oslo: Institute for Research, University of Oslo; 2004.

140. Bere $E$, Veierod MB, Bjelland M, Klepp Kl: Outcome and process evaluation of a Norwegian school-randomized fruit and vegetable intervention: Fruits and Vegetables Make the Marks (FVMM). Heal Educ Res 2006, 21(2):258-267.

141. Bere E, Veierod MB, Klepp Kl: The Norwegian School Fruit Programme: evaluating paid vs. no-cost subscriptions. Prev Med 2005, 41(2):463-470

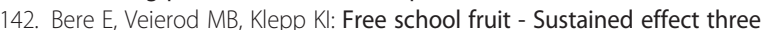
years later. Int J Behav Nutr Phys Act 2007, 4(1):5-10.

143. Birnbaum AS, Lytle LA, Story M, Perry CL, Murray DM: Are differences in exposure to a multicomponent school-based intervention associated with varying dietary outcomes in adolescents? Health Educ Behav Off Publ Soc Public Health Educ 2002, 29(4):427-443. 
144. Blom-Hoffman J, Kelleher C, Power TJ, Leff SS: Promoting healthy food consumption among young children: evaluation of a multi-component nutrition education program. J Sch Psychol 2004, 42(1):45-60

145. Blom-Hoffman J, Wilcox KR, Dunn L, Leff SS, Power TJ: Family involvement in school-base health promotion: bringing nutrition information home. Sch Psychol Rev 2008, 37(4):567-577.

146. Byrd-Bredbenner C, O'Connell LH, Shannon B: Junior high home economics curriculum: its effect on students' knowledge, attitude, and behavior. Home Econ Res J 1982, 11(2):123-133.

147. Coates TJ, Barofsky I, Saylor KE: Modifying the snack food consumption patterns of inner city high school students: the Great Sensations study. Prev Med 1985, 14(2):234-247.

148. Contento IR, Koch PA, Lee H, Calabrese-Barton A: Adolescents demonstrate improvement in obesity risk behaviors after completion of choice, control \& change, a curriculum addressing personal agency and autonomous motivation. J Am Diet Assoc 2010, 110(12):1830-1839.

149. Cooke LJ, Chambers LC, Anez EV, Croker HA, Boniface D, Yeomans MR, Wardle J: Eating for pleasure or profit: the effect of incentives on children's enjoyment of vegetables. Psychol Sci 2011, 22(2):190-196.

150. Crockett SJ, Mullis R, Perry CL, Luepker RV: Parent education in youthdirected nutrition interventions. Prev Med 1989, 18(4):475-491.

151. Cullen KW, Bartholomew LK, Parcel GS: Girl Scouting: an effective channel for nutrition education. J Nutr Educ 1997, 29(2):86-91.

152. Cullen KW, Smalling A, Thompson D, Watson KB, Reed D, Konzelmann K: Creating healthful home food environments: results of a study with participants in the expanded food and nutrition education program. $J$ Nutr Educ Behav 2009, 41(6):380-388.

153. Day ME, Strange KS, McKay HA, Naylor P: Action schools! BC - healthy eating: effects of a whole-school model to modifying eating behaviours of elementary school children. Can J Public Health 2008, 99(4):328-331.

154. Domel SB, Baranowski T, Davis H, Thompson WO, Leonard SB, Riley P, Baranowski J, Dudovitz B, Smyth M: Development and evaluation of a school intervention to increase fruit and vegetable consumption among 4th and 5th grade students. J Nutr Educ 1993, 25(6):345-349.

155. Dzewaltowski DA, Estabrooks PA, Welk G, Hill J, Milliken G, Karteroliotis K, Johnston JA: Healthy youth places: A randomized controlled trial to determine the effectiveness of facilitating adult and youth leaders to promote physical activity and fruit and vegetable consumption in middle schools. Health Educ Behav Off Publ Soc Public Health Educ 2009, 36(3):583-600

156. Fatohy IM, Mounir GM, Mahdy NH, El-Deghedi BM: Improving students' knowledge, attitude and practice towards cancer prevention through a health education program. Part II. J Egypt Public Health Assoc 1998, 73(5-6):755-785.

157. Foerster SB, Gregson J: The California Children's 5 a Day Power Play! Campaign: Evaluation Study of Activities in the School Channel. Sacremento: California Department of Health Services and California Public Health Foundation; 1996.

158. Fogarty AW, Antoniak M, Venn AJ, Davies L, Goodwin A, Salfield N, Stocks J, Britton J, Lewis SA: Does participation in a population-based dietary intervention scheme have a lasting impact on fruit intake in young children? Int J Epidemiol 2007, 36(5):1080-1085.

159. Foster GD, Sherman S, Borradaile KE, Grundy KM, Vander Veur SS, Nachmani J, Karpyn A, Kumanyika S, Shults J: A policy-based school intervention to prevent overweight and obesity. Pediatrics 2008, 121(4):e794-e802.

160. Fulkerson JA, French SA, Story M, Nelson H, Hannan PJ: Promotions to increase lower-fat food choices among students in secondary schools: description and outcomes of TACOS (Trying Alternative Cafeteria Options in Schools). Public Health Nutr 2004, 7(5):665-674.

161. Gentile DA, Welk G, Eisenmann JC, Reimer RA, Walsh DA, Russell DW Callahan R, Walsh M, Strickland S, Fritz K: Evaluation of a multiple ecological level child obesity prevention program: Switch what you Do, View, and Chew. BMC Med 2009, 7:49. 1741

162. German MJ, Pearce J, Wyse BW, Hansen RG: A nutrition component for high school health education curriculums. J Sch Heal 1981, 51(3):149-153.

163. Gortmaker SL, Peterson K, Wiecha J, Sobol AM, Dixit S, Fox MK, Laird N: Reducing obesity via a school-based interdisciplinary intervention among youth: Planet Health. Arch Pediatr Adolesc Med 1999, 153(4):409-418.

164. Govula C: Culturally Appropriate Nutrition Lessons Increased Fruit and Vegetable Consumption in American Indian Children. United States: South Dakota State University; 2007:54
165. Green NR, Munrow SG: Evaluating nutrient-based nutrition education by nutrition knowledge and school lunch plate waste. Sch Food Serv Res Rev 1987, 11(2):112-115.

166. Haerens L, Deforche B, Maes L, Cardon G, Stevens V, De Bourdeaudhuij I: Evaluation of a 2-year physical activity and healthy eating intervention in middle school children. Heal Educ Res 2006, 21(6):911-921.

167. Haire-Joshu D, Nanney MS, Elliott M, Davey C, Caito N, Loman D, Brownson $\mathrm{RC}$, Kreuter MW: The use of mentoring programs to improve energy balance behaviors in high-risk children. Obesity 2010, 18(SUPPL. 1):S75-S83.

168. Hassapidou MN, Fotiadou E, Maglara E: A nutrition intervention programme for lower secondary schools in Greece. Heal Educ J 1997, 56(2):134-144.

169. Hazlegrove S: Step up MyPyramid - Comparing Teaching Methods for Limited Resource Elementary School Children: A Pilot Study. United States: The University of North Carolina at Greensboro; 2009:76.

170. He M, Beynon C, Sangster Bouck M, St Onge R, Stewart S, Khoshaba L, Horbul BA, Chircoski B: Impact evaluation of the Northern Fruit and Vegetable Pilot Programme - a cluster-randomised controlled trial. Public Health Nutrition 2009, 12(11):2199-2208.

171. Head MK: A nutrition education program at three grade levels. J Nutr Educ 1974, 6(56):59.

172. Hoffman JA, Franko DL, Thompson DR, Power TJ, Stallings VA: Longitudinal behavioral effects of a school-based fruit and vegetable promotion program. J Pediatr Psychol 2010, 35(1):61-71.

173. Hoffman JA, Thompson DR, Franko DL, Power TJ, Leff SS, Stallings VA: Decaying behavioral effects in a randomized, multi-year fruit and vegetable intake intervention. Prev Med 2011, 52(5):370-375.

174. Hopper CA, Gruber MB, Munoz KD, MacConnie S: School-based cardiovascular exercise and nutrition programs with parent participation. $J$ Health Educ Assoc Adv Health Educ 1996, 27(5):S32-S39.

175. Hoppu U, Lehtisalo J, Kujala J, Keso T, Garam S, Tapanainen H, Uutela A, Laatikainen T, Rauramo U, Pietinen P: The diet of adolescents can be improved by school intervention. Public Health Nutr 2010, 13(6A):973-979.

176. Horne PJ, Hardman CA, Lowe CF, Tapper K, Le Noury J, Madden P, Patel P, Doody M: Increasing parental provision and children's consumption of lunchbox fruit and vegetables in Ireland: the food Dudes intervention. Eur J Clin Nutr 2009, 63(5):613-618.

177. House J: Effectiveness of the 5-TODAY program at increasing fruit and vegetable consumption in grade five and six children. In Masters thesis. Vancouver, Canada: University of British Columbia, Human Nutrition Department; 2005

178. Jemmott JB III, Jemmott LS, O'Leary A, Ngwane Z, Icard L, Bellamy S, Jones S, Landis J, Heeren G, Tyler JC, Makiwane MB: Cognitive-behavioural health-promotion intervention increases fruit and vegetable consumption and physical activity among South African adolescents: a cluster-randomised controlled trial. Psychol Health 2011, 26(2):167-185.

179. Kipping RR, Jago R, Lawlor DA: Diet outcomes of a pilot school-based randomised controlled obesity prevention study with 9-10 year olds in England. Prev Med Int J Dev Pract Theory 2010, 51(1):56-62.

180. Kirks BA, Hendricks DG, Wyse BW: Parent involvement in nutrition education for primary grade students. J Nutr Educ 1982, 14(4):137-140.

181. Klesges RC, Obarzanek E, Kumanyika S, Murray DM, Klesges LM, Relyea GE, Stockton MB, LanCtot JQ, Beech BM, McClanahan BS, Sherrill-Mittleman D, Slawson DL: The Memphis Girls' health Enrichment Multi-site Studies (GEMS): an evaluation of the efficacy of a 2-year obesity prevention program in African American girls. Arch Pediatr Adolesc Med 2010, 164(11):1007-1014

182. Koch PA: A comparison of Two Nutrition Education Curricula: Cookshops and Food and Environment Lessons. United States: Columbia University Teachers College; 2000:170.

183. Kristal AR, Goldenhar L, Muldoon J, Morton RF: Evaluation of a supermarket intervention to increase consumption of fruits and vegetables. Am J Health Promot AJHP 1997, 11(6):422-425.

184. Kristjansdottir AG, Johannsson E, Thorsdottir I: Effects of a school-based intervention on adherence of 7-9-year-olds to food-based dietary guidelines and intake of nutrients. Public Health Nutr 2010, 13(8):1151-1161.

185. Leroy JL, Gadsden P, Rodriguez-Ramirez S, De Cossio TG: Cash and in-kind transfers in poor rural communities in Mexico increase household fruit, vegetable, and micronutrient consumption but also lead to excess energy consumption. J Nutr 2010, 140(3):612-617. 
186. Lewis M, Brun J, Talmage H, Rasher S: Teenagers and food choices: the impact of nutrition education. J Nutr Educ 1988, 20(6):336-340.

187. Lo E, Coles R, Humbert ML, Polowski J, Henry CJ, Whiting SJ: Beverage intake improvement by high school students in Saskatchewan, Canada. Nutr Res 2008, 28(3):144-150.

188. Lubans DR, Morgan PJ, Callister R, Collins CE, Plotnikoff RC: Exploring the mechanisms of physical activity and dietary behavior change in the Program X intervention for adolescents. J Adolesc Heal 2010, 47(1):83-91.

189. Luepker RV, Perry CL, McKinlay SM, Nader PR, Parcel GS, Stone EJ, Webber LS, Elder JP, Feldman HA, Johnson CC: Outcomes of a field trial to improve children's dietary patterns and physical activity. The Child and Adolescent Trial for Cardiovascular Health. CATCH collaborative group. JAMA J Am Med Assoc 1996, 275(10):768-776.

190. Lytle LA, Murray DM, Perry CL, Story M, Birnbaum AS, Kubik MY, Varnell S: School-based approaches to affect adolescents' diets: Results from the TEENS study. Health Educ Behav Off Publ Soc Public Health Educ 2004, 31(2):270-287.

191. Mangunkusumo RT, Brug J, de Koning HJ, van der Lei J, Raat H: Schoolbased internet-tailored fruit and vegetable education combined with brief counselling increases children's awareness of intake levels. Public Health Nutr 2007, 10(3):273-279.

192. Martens MK, van Assema P, Paulussen TGWM, Van Breukelen G, Brug J: Krachtvoer: effect evaluation of a Dutch healthful diet promotion curriculum for lower vocational schools - Duplicate of Ref ID 90030. Public Health Nutr 2008, 11(3):271-278.

193. Mauriello LM, Ciavatta MM, Paiva AL, Sherman KJ, Castle PH, Johnson JL, Prochaska JM: Results of a multi-media multiple behavior obesity prevention program for adolescents. Prev Med 2010, 51(6):451-456.

194. Moore L, Tapper K: The impact of school fruit tuck shops and school food policies on children's fruit consumption: a cluster randomised trial of schools in deprived areas. J Epidemiol Community Health 2008, 62(10):926-931.

195. Muth ND, Chatterjee A, Williams D, Cross A, Flower K: Making an IMPACT: effect of a school-based pilot intervention. N C Med J 2008, 69(6):432-440.

196. Neumark-Sztainer D, Story M, Hannan PJ, Rex J: New Moves: a school-based obesity prevention program for adolescent girls. Prev Med 2003, 37(1):41-51.

197. Nicklas TA, Dwyer J, Mitchell P, Zive M, Montgomery D, Lytle L, Cutler J, Evans M, Cunningham A, Bachman K, Nichaman M, Snyder P: Impact of fat reduction on micronutrient density of children's diets: the CATCH Study. Prev. Med. 1996, 25(4):478-485.

198. Nicklas TA, Johnson CC, Myers L, Farris RP, Cunningham A: Outcomes of a high school program to increase fruit and vegetable consumption: Gimme 5-a fresh nutrition concept for students. J Sch Heal 1998, 68(6):248-253.

199. O'Connell KM: Impact of the HEROS (Healthy Eating to Reduce Obesity through Schools) Study on healthy food choices and obesity among middle school students in Guilford County (North Carolina) schools. United States: The University of North Carolina at Greensboro; 2005:233.

200. Panunzio MF, Antoniciello A, Pisano A, Dalton S: Nutrition education intervention by teachers may promote fruit and vegetable consumption in Italian students. Nutr Res 2007, 27(9):524-528.

201. Parcel GS, Simons-Morton B, O'Hara NM, Baranowski T, Wilson B: School promotion of healthful diet and physical activity: impact on learning outcomes and self-reported behavior. Heal EduC Q 1989, 16(2):181-199.

202. Parker L, Fox A: The Peterborough Schools Nutrition Project: a multiple intervention programme to improve school-based eating in secondary schools. Public Health Nutr 2001, 4(6):1221-1228.

203. Parmer SM, Salisbury-Glennon J, Shannon D, Struempler B: School gardens: an experiential learning approach for a nutrition education program to increase fruit and vegetable knowledge, preference, and consumption among second-grade students. J Nutr Educ Behav 2009, 41(3):212-217.

204. Passmore S, Harris G: School nutrition action groups and their effect upon secondary school-aged pupils' food choices. Nutr Bull 2005, 30:364-369.

205. Perry CL, Bishop DB, Taylor G, Murray DM, Mays RW, Dudovitz BS, Smyth M, Story M: Changing fruit and vegetable consumption among children: the 5-a-Day Power Plus Program in St. Paul, Minnesota. Am J Public Health 1998, 88(4):603-609.

206. Perry CL, Bishop DB, Taylor GL, Davis M, Story M, Gray C, Bishop SC, Mays RAW, Lytle $L A$, Harnack L: A randomized school trial of environmental strategies to encourage fruit and vegetable consumption among children. Health Educ Behav Off Publ Soc Public Health Educ 2004, 31(1):65-76.
207. Perry CL, Luepker RV, Murray D, Kurth C, Mullis R, Crockett S, Jacobs DR Jr: Parent involvement with children's health promotion: the Minnesota home team. Am J Public Health 1988, 78(9):1156-1160.

208. Perry CL, Lytle LA, Feldman H, Nicklas T, Stone E, Zive M, Garceau A, Kelder SH: Effects of the Child and Adolescent Trial for Cardiovascular Health (CATCH) on fruit and vegetable intake. J Nutr Educ 1998, 30(6):354-360.

209. Perry CL, Mullis R, Maile M: Modifying eating behavior of children: a pilot intervention study. J Sch Heal 1985, 55(10):399-402.

210. Powers AR, Struempler BJ, Guarino A, Parmer SM: Effects of a nutrition education program on the dietary behavior and nutrition knowledge of second-grade and third-grade students. J Sch Heal 2005, 75(4):129-133.

211. Prochaska JJ, Sallis JF: A randomized controlled trial of single versus multiple health behavior change: promoting physical activity and nutrition among adolescents. Health Psychol Off J Div Health Psychol Am Psychol Assoc 2004, 23(3):314-318.

212. Quinn $L$, Horacek TM, Castle J: The impact of COOKSHOP on the dietary habits and attitudes of fifth graders. Top Clin Nutr 2003, 18(1):42-48.

213. Radcliffe B, Ogden C, Welsh J, Carroll S, Coyne T, Craig P: The Queensland School Breakfast Project: a health promoting schools approach. Nutr Diet 2005, 62:33-40.

214. Raju S, Rajagopal P, Gilbride TJ: Marketing healthful eating to children: the effectiveness of incentives, pledges, and competitions. J Mark 2010, 74(3):93-106.

215. Ransley JK, Greenwood DC, Cade JE, Blenkinsop S, Schagen I, Teeman D, Scott E, White G, Schagen S: Does the school fruit and vegetable scheme improve children's diet? A non-randomised controlled trial. J Epidemiol Community Health 2007, 61(8):699-703.

216. Rees G, Bakhshi S, Surujlal-Harry A, Stasinopoulos M, Baker A: A computerised tailored intervention for increasing intakes of fruit, vegetables, brown bread and wholegrain cereals in adolescent girls. Public Health Nutr 2010, 13(8):1271-1278.

217. Reinaerts $E$, de Nooijer J, Candel M, de Vries N: Increasing children's fruit and vegetable consumption: distribution or a multicomponent programme? Public Health Nutr 2007, 10(9):939-947.

218. Resnicow K, Davis M, Smith M, Baranowski T, Lin LS, Baranowski J, Doyle C, Wang DT: Results of the TeachWell worksite wellness program. Am J Public Health 1998, 88(2):250-257.

219. Reynolds KD, Bishop DB, Chou CP, Xie B, Nebeling L, Perry CL: Contrasting mediating variables in two 5-a-day nutrition intervention programs. Prev Med 2004, 39(5):882-893.

220. Reynolds KD, Franklin FA, Binkley D, Raczynski JM, Harrington KF, Kirk KA, Person S: Increasing the fruit and vegetable consumption of fourthgraders: results from the high 5 project. Prev Med 2000, 30(4):309-319.

221. Ryan $L$ : The effect of nutrition education on improving fruit and vegetable consumption of youth. J Ext 1995, 33(5):. Feature Articles 5FEA3. (Epublication).

222. Sahota P, Rudolf MC, Dixey R, Hill AJ, Barth JH, Cade J: Randomised controlled trial of primary school based intervention to reduce risk factors for obesity. BMJ (Clinical research ed.) 2001, 323(7320):1029-1032

223. Shannon B, Chen AN: A three-year school-based nutrition education study. J Nutr Educ 1988, 20(34):114-124.

224. Shemilt I, Harvey I, Shepstone L, Swift L, Reading R, Mugford M, Belderson P, Norris $\mathrm{N}$, Thoburn J, Robinson J: A national evaluation of school breakfast clubs: evidence from a cluster randomized controlled trial and an observational analysis. Child Care Health Dev 2004, 30(5):413-427.

225. Siega-Riz AM, El Ghormli L, Mobley C, Gillis B, Stadler D, Hartstein J, Volpe SL, Virus A, Bridgman J: The effects of the HEALTHY study intervention on middle school student dietary intakes. Int J Behav Nutr Phys Act 2011, 8(7): (Epublication).

226. Smith HM, Justice CL: Effects of nutrition programs on third grade students. J Nutr Educ 1979, 11:92-95.

227. Smolak L, Levine MP, Schermer F: A controlled evaluation of an elementary school primary prevention program for eating problems. J Psychosom Res 1998, 44(3-4):339-353.

228. Spiegel SA, Foulk D: Reducing overweight through a multidisciplinary school-based intervention. Obesity (Silver Spring, Md.) 2006, 14(1):88-96.

229. Taylor RW, McAuley KA, Barbezat W, Strong A, Williams SM, Mann Jl: APPLE Project: 2-y findings of a community-based obesity prevention program in primary school age children. Am J Clin Nutr 2007, 86(3):735-742.

230. te Velde SJ, Brug J, Wind M, Hildonen C, Bjelland M, Perez-Rodrigo C, Klepp KI: Effects of a comprehensive fruit- and vegetable-promoting school- 
based intervention in three European countries: The Pro Children Study. Br J Nutr 2008, 99(4):893-903.

231. Thompson D, Baranowski T, Baranowski J, Cullen K, Jago R, Watson K, Liu Y: Boy Scout 5-a-Day Badge: outcome results of a troop and Internet intervention. Prev Med 2009, 49(6):518-526.

232. Thompson V, Cullen KW, Watson KB, Zakeri I: The increased availability and marketing of fruit, juice, and vegetables to middle school students increases consumption. J Child Nutr Manag (Online) 2007, Spring 2007(1): (Epublication).

233. Weaver M, Poehlitz M, Hutchison S: 5 a day for low-income families: evaluation of an advertising campaign and cooking events. J Nutr Educ 1999, 31(3):161-169

234. White AA, Skinner JD: Can goal setting as a component of nutrition education effect behavior change among adolescents? J Nutr Educ 1988 20(6):327-335.

235. Wilson DK, Friend R, Teasley N, Green S, Reaves IL, Sica DA: Motivational versus social cognitive interventions for promoting fruit and vegetable intake and physical activity in African American adolescents. Ann Behav Med 2002, 24(4):310-319.

236. Wind M, Bjelland M, Pacrez-Rodrigo C, te Velde SJ, Hildonen C, Bere E, Klepp $\mathrm{Kl}$, Brug J: Appreciation and implementation of a school-based intervention are associated with changes in fruit and vegetable intake in 10- to 13-year old schoolchildren-the Pro Children study. Heal Educ Res 2008, 23(6):997-1007.

237. Winett RA, Roodman AA, Winett SG, Bajzek W, Rovniak LS, Whiteley JA: The effects of the Eat4Life Internet-based health behavior program on the nutrition and activity practices of high school girls. J Gend Cult Heal 1999, 4(3):239-254.

238. Belansky ES, Cutforth N, Delong E, Litt J, Gilbert L, Scarbro S, Beatty B, Romaniello C, Brink L, Marshall JA: Early effects of the federally mandated local wellness policy on school nutrition environments appear modest in Colorado's rural, low-income elementary schools. J Am Diet Assoc 2010, 110(11):1712-1717.

239. Bere E, Klepp KI: Free vs. Paid School Fruit: big difference with respect to social inequality. In Ethics and the Politics of Food. Edited by Kaiser M, Lien ME. Wageningen, Netherlands: Academic Publishers; 2006:353-357.

240. Birmingham B, Shultz JA, Edlefsen M: Evaluation of a five-a-day recipe booklet for enhancing the use of fruits and vegetables in low-income households. J Community Health 2004, 29(1):45-62.

241. Brown BJ, Hermann JR: Gem no. 395. Cooking classes increase fruit and vegetable intake and food safety behaviors in youth and adults. J Nutr Educ Behav 2005, 37(2):104-105.

242. Caldwell EM, Miller Kobayashi M, DuBow WM, Wytinck SM: Perceived access to fruits and vegetables associated with increased consumption. Public Health Nutr 2009, 12(10):1743-1750.

243. Canavera M, Sharma M, Murnan J: Development and pilot testing a social cognitive theory-based intervention to prevent childhood obesity among elementary students in rural Kentucky. Int Q Community Health Educ 2008, 29(1):57-70.

244. Cassady D, Vogt R, Oto-Kent D, Mosley R, Lincoln R: The power of policy: a case study of healthy eating among children. Am J Public Health 2006, 96(9):1570-1571.

245. Centers for Disease, Control and Prevention: Evaluation of a fruit and vegetable distribution program-Mississippi, 2004-05 school year. MMWR 2006, 55(35):957-961.

246. Clawson B, Sumner SK, McPherson EP: Effectiveness of a school-based community approach to nutrition education for adolescents. Sch Food Serv Res Rev 1984, 8:105-109.

247. Colby SE: The Development of Peer-Led Youth Theater as a Nutrition Education Tool to Promote the Healthy Traditional Latino Diet. United States: The University of North Carolina at Greensboro; 2005:163.

248. Contento IR, Koch PA, Lee H, Sauberli W, Calabrese-Barton A: Enhancing personal agency and competence in eating and moving: Formative evaluation of a middle school curriculum-Choice, Control, and Change. $J$ Nutr Educ Behav 2007, 39(5, Suppl):S179-S186.

249. Coyle KK, Potter S, Schneider D, May G, Robin LE, Seymour J, Debrot K Distributing free fresh fruit and vegetables at school: results of a pilot outcome evaluation. Public Health Rep 2009, 124(5):660-669.

250. Cullen KW, Hartstein J, Reynolds KD, Vu M, Resnicow K, Greene N, White MA: Improving the school food environment: results from a pilot study in middle schools. J Am Diet Assoc 2007, 107(3):484-489.
251. Cullen KW, Thompson D: Feasibility of an 8-week African American webbased pilot program promoting healthy eating behaviors: Family Eats. Am J Heal Behav 2008, 32(1):40-51.

252. Cullen KW, Watson KB: The impact of the Texas public school nutrition policy on student food selection and sales in Texas. Am J Public Health 2009, 99(4):706-712.

253. Cullen KW, Watson K, Zakeri I: Improvements in middle school student dietary intake after implementation of the Texas Public School Nutrition Policy. Am J Public Health 2008, 98(1):111-117.

254. Cullen KW, Watson KB, Zakeri I, Baranowski T, Baranowski JH: Achieving fruit, juice, and vegetable recipe preparation goals influences consumption by 4th grade students. Int I Behav Nutr Phys Act 2007, 4(28): (Epublication).

255. Cullen KW, Zakeri I, Pryor EW, Baranowski T, Baranowski J, Watson K: Goal setting is differentially related to change in fruit, juice, and vegetable consumption among fourth-grade children. Health Behav Off Publ Soc Public Health Educ 2004, 31(2):258.

256. Cullen KW, Watson K, Zakeri I, Ralston K: Exploring changes in middle school student lunch consumption after local school food service policy modifications. Public Health Nutr 2006, 9(6):814-820.

257. DelCampo D, Baca JS, Jimenez D, Sanchez PR, DelCampo R: Just be it. healthy and fit increases fifth graders' fruit and vegetable intake, physical activity, and nutrition knowledge. J Ext 2011, 49(1): Research in Brief 1RIB5. (Epublication).

258. Engels HJ, Gretebeck RJ, Gretebeck KA, Jimenez L: Promoting healthful diets and exercise: efficacy of a 12-week after-school program in urban African Americans. J Am Diet Assoc 2005, 105(3):455-459.

259. Freedman MR, Nickell A: Impact of after-school nutrition workshops in a public library setting. J Nutr Educ Behav 2010, 42(3):192-196.

260. French SA, Story M, Jeffery RW, Snyder P, Eisenberg M, Sidebottom A, Murray D: Pricing strategy to promote fruit and vegetable purchase in high school cafeterias. J Am Diet Assoc 1997, 97(9):1008-1010.

261. Greenwood B, Ralston PA, Young-Clark I, Cornille T, Brown LL, Davis KE, Salley TJ, Goehrig MH, Mullins AP, Gaskins DJ: Nutrition education initiative: a school-based program to promote healthy eating practices of preadolescents. J Fam Consum Sci 2009, 101(2):47-52.

262. Goldberg JP, Collins JJ, Folta SC, McLarney MJ, Kozower C, Kuder J, Clark V, Economos CD: Retooling food service for early elementary school students in Somerville, Massachusetts: the Shape Up Somerville experience. Prev Chron Dis 2009, 6(3):A103.

263. Grainger C, Senauer B, Runge CF: Nutritional improvements and student food choices in a school lunch program. J Consum Aff 2007, 41(2):265-284

264. Haroun D, Harper C, Wood L, Nelson M: The impact of the food-based and nutrient-based standards on lunchtime food and drink provision and consumption in primary schools in England. Public Health Nutr 2011 14(2):209-218

265. Heim S, Bauer KW, Stang J, Ireland M: Can a community-based intervention improve the home food environment? parental perspectives of the influence of the delicious and nutritious garden. $J$ Nutr Educ Behav 2011, 43(2):130-134.

266. Heim S, Stang J, Ireland M: A garden pilot project enhances fruit and vegetable consumption among children. J Am Diet Assoc 2009, 109(7):1220-1226.

267. Hermann JR, Parker SP, Brown BJ, Siewe YJ, Denney BA, Walker SJ: Afterschool gardening improves children's reported vegetable intake and physical activity. J Nutr Educ Behav 2006, 38(3):201-202.

268. Horne PJ, Lowe CF, Fleming PF, Dowey AJ: An effective procedure for changing food preferences in 5-7-year-old children. Proc Nutr Soc 1995, 54(2):441-452

269. Howison D, Neidermyer F, Shortridge R: Field testing a fifth-grade nutrition education program designed to change food-selection behavior. J Nutr Educ 1988, 20(2):82-86.

270. Jones JH Jr: Evaluation of the Louisiana Nutrition Education Program. Baton Rouge: Louisiana State University; 1970.

271. Koch S, Waliczek TM, Zajicek JM: The effect of a summer garden program on the nutritional knowledge, attitudes, and behaviors of children. HortTechnol 2006, 16(4):620-625.

272. Kuczmarski MF, Aljadir L: Gem no. 364. Using food calendars to selfmonitor: got 5? Nutrition for Kids program. J Nutr Educ Behav 2003, 35(5):269-270. 
273. Latimer M: The Role of Flavor-Flavor Conditioning and Sensory-Based, Vegetable-Themed Education in Increasing Vegetable Consumption in Elementary School-Aged Children. United States: Utah State University; 2009:239.

274. Laurence S, Peterken R, Burns C: Fresh Kids: the efficacy of a Health Promoting Schools approach to increasing consumption of fruit and water in Australia. Heal Promot Int 2007, 22(3):218-226.

275. Lautenschlager L, Smith C: Understanding gardening and dietary habits among youth garden program participants using the Theory of Planned Behavior. Appetite 2007, 49(1):122-130.

276. Lee A, Ho M, Keung V: Healthy school as an ecological model for prevention of childhood obesity. Res Sports Med 2010, 18(1):49-61.

277. Lindholm BW, Touliatos J, Wenberg MF: Predicting changes in nutrition knowledge and dietary quality in ten to thirteen-year-olds following a nutrition education program. Adolescence 1984, 14:370-375.

278. Lineberger SE, Zajicek JM: School gardens: can a hands-on teaching tool affect students' attitudes and behaviors regarding fruit and vegetables? HortTechnology 2000, 10(3):593-597.

279. Long JD, Armstrong ML, Amos E, Shriver B, Roman-Shriver C, Feng D, Harrison L, Luker S, Nash A, Blevins MW: Pilot using World Wide Web to prevent diabetes in adolescents. Clin Nurs Res 2006, 15(1):67-79.

280. Lowe CF, Horne PJ, Tapper K, Bowdery M, Egerton C: Effects of a peer modelling and rewards-based intervention to increase fruit and vegetable consumption in children. Eur J Clin Nutr 2004, 58(3):510-522.

281. Lowe F, Horne P: In Food Dudes. Increasing Children's Consumption of Fruit and Vegetables. Changing the Nation's Diet: a Programme to Increase Children's Consumption of Fruit and Vegetables. Edited by B. University of Wales. Wales: Bangor; 2007.

282. Maddock J, Takeuchi L, Netta B, Tanaka C, Irvin L, Matsuoka C, Wood B Evaluation of a statewide program to reduce chronic disease: The Healthy Hawaii Initiative, 2000-2004. Eval Program Plan 2006, 29(3):293-300.

283. Martens M, van Assema P, Knibbe R, Engels RC, Brug J: Family environmental factors do not explain differences in the behavioral effect of a healthy diet promotion program in lower vocational schools among 12- to 14-year-old adolescents. Am J Health Promot AJHP 2010, 24(3):182-185.

284. Matusky J, Gilboy M, Anderson K: A collaborative model for nutrition education in elementary schools changes the fruit and vegetable consumption of second grade students. J Am Diet Assoc 2009, 109(9, Supplement 1):A83-A83.

285. McCormick A, Kattelmann K, Ren C, Richards A, Wells K: "Fun fruit and veggie event" enhances acceptance of fruits and vegetables in schoolaged children. Top Clin Nutr 2009, 24(3):252-261.

286. Medina J: A Dose Response Analysis of a School-Based Nutrition Intervention in Middle School Children. United States: The University of Texas School of Public Health; 2009:113.

287. Mozaffarian RS, Wiecha JL, Roth BA, Nelson TF, Lee RM, Gortmaker SL: Impact of an organizational intervention designed to improve snack and beverage quality in YMCA after-school programs. Am J Public Health 2010, 100(5):925-932.

288. Mullally ML, Taylor JP, Kuhle S, Bryanton J, Hernandez KJ, MacLellan DL, McKenna ML, Gray RJ, Veugelers PJ: A province-wide school nutrition policy and food consumption in elementary school children in Prince Edward Island. Can J Public Health 2010, 101(1):40-43.

289. Nelson M, Lowes K, Hwang V: The contribution of school meals to food consumption and nutrient intakes of young people aged 4-18 years in England. Public Health Nutr 2007, 10:652-662.

290. Panunzio MF, Antoniciello A, Cela EP, Ferguson LR, Bucci E, Petracca L, Bisceglia R, D'Ambrosio P, Buccinotti MC, Romagnolo G, D'Aprile AP, Carella F, Ugolini G: 15-week long school-based nutritional education program to promote Italian primary schoolchildren's fruit and vegetable intake. Ann lg 2010, 22(5):481-484

291. Perez-Rodrigo C, Aranceta J: Nutrition education for schoolchildren living in a low-income Urban Area in Spain. J Nutr Educ 1997, 29(5):267-273.

292. Perrin EM, Jacobson Vann JC, Benjamin JT, Skinner AC, Wegner S, Ammerman AS: Use of a pediatrician toolkit to address parental perception of children's weight status, nutrition, and activity behaviors. Acad Pediatr 2010, 10(4):274-281.

293. Resnicow K, Yaroch AL, Davis A, Wang DT, Carter S, Slaughter L, Coleman D, Baranowski T: GO GIRLS!: results from a nutrition and physical activity program for low-income, overweight African American adolescent females. Health Educ Behav Off Publ Soc Public Health Educ 2000, 27(5):616-631.

294. Rinderknecht K, Smith C: Social cognitive theory in an after-school nutrition intervention for urban Native American youth. J Nutr Educ Behav 2004, 36(6):298-304.

295. Scampini R, Bandini L, Curtin C, Gleason J, Must A, Maslin M, Fleming R: Changes in fruit, vegetable and sweetened beverage intake in adolescents and young adults with down syndrome participating in a parent supported weight reduction program. Obesity 2008, 16(S1):S307-S307.

296. Seo D: Comparison of school food policies and food preparation practices before and after the local wellness policy among Indiana high schools. Am J Heal Educ 2009, 40(3):165-173.

297. Slusser WM, Cumberland WG, Browdy BL, Lange L, Neumann C: A school salad bar increases frequency of fruit and vegetable consumption among children living in low-income households. Public Health Nutr 2007, 10(12):1490-1496.

298. Spoon MD, Benedict J, Leontos C, Krelle-Zepponi N: Increasing fruit and vegetable consumption among middle school students: implementing the 5-a-day program. J Ext 1998, 36(4):. Feature Articles 4FEA4. (Epublication).

299. Stawinski M, Jaworowicz-Szczepaniak M, Adamek R, Maksymiuk T: Results of introducing a health education programme in a Poznan kindergarten - A preliminary study. Fam Med Prim Care Rev 2008, 10(4):1335-1340.

300. Teeman D, Blenkinsop S, Ransley J, Schagen I, Schagen S, Scott E, White G: Evaluation of the Big Lottery Fund's National School Fruit and Vegetable Scheme: Second Interim Report. London, UK: National Foundation for Educational Research; 2004

301. Trevino RP, Pugh JA, Hernandez AE, Menchaca VD, Ramirez RR, Mendoza M: Bienestar: a diabetes risk-factor prevention program. J Sch Heal 1998, 68(2):62-67.

302. Tse MMY, Yuen DTW: Effects of providing a nutrition education program for teenagers: dietary and physical activity patterns. Nurs Heal Sci 2009, 11(2):160-165.

303. Walker SJ: Effect of an After School Education and Gardening Program on Nutrition and Physical Activity Behaviors in School Age Youth, Grades 3-8. United States: Oklahoma State University; 2006:1-91.

304. Wang MC, Rauzon S, Studer N, Martin AC, Craig L, Merlo C, Fung K, Kursunoglu D, Shannguan $M$, Crawford $P$ : Exposure to a comprehensive school intervention increases vegetable consumption. J Adolesc Heal 2010, 47(1):74-82.

305. Wright W, Rowell Laura RD: Examining the effect of gardening on vegetable consumption among youth in kindergarten through fifth grade. Wis Med J 2010, 109(3):124-129.

306. Wrigley N: Assessing the impact of improved retail access on diet in a 'Food Desert': a preliminary report. Urban Stud 2002, 11:2061-2082.

307. Boyd S, Dingle R, Campbell R: Taking a Bite of the Apple: The Implementation of Fruit in Schools (Healthy Futures Evaluation Report to the Minitry of Health). Wellington: New Zealand Council for Educational Research; 2007.

308. Forneris T, Fries E, Meyer A, Buzzard M, Uguy S, Ramakrishnan R, Lewis C, Danish S: Results of a rural school-based peer-led intervention for youth: Goals for health. J Sch Heal 2010, 80(2):57-65.

309. Gorely T, Nevill ME, Morris JG, Stensel DJ, Nevill A: Effect of a school-based intervention to promote healthy lifestyles in 7-11 year old children. Int J Behav Nutr Phys Act 2009, 6:5 (Epublication).

310. Somerset S, Markwell K: Impact of a school-based food garden on attitudes and identification skills regarding vegetables and fruit: a 12-month intervention trial. Public Health Nutr 2009, 12(2):214-221.

311. Agency for Healthcare Research and Quality: Efficacy of Interventions to Modify Dietary Behavior Related to Cancer Risk. Rockville: AHRQ Publication No. 01-E028; 2000:1-5.

312. Bere E: Increasing School-Children's Intake of Fruit and Vegetables: Fruits and Vegetables make the Marks. Oslo: University of Oslo; 2003.

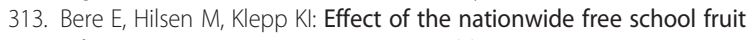
scheme in Norway. Br J Nutr 2010, 104(4):589-594.

314. Bere $E$, Veierod MB, Bjelland M, Klepp KI: Free school fruit-sustained effect 1 year later. Heal Educ Res 2006, 21(2):268-275.

315. Bere E, Klepp Kl: Changes in accessibility and preferences predict children's future fruit and vegetable intake. Int J Behav Nutr Phys Act 2005, 2:15. 
316. Byrd-Bredbenner C, O'Connell LH, Shannon B, Eddy JM: A nutrition curriculum for health education: its effect on students' knowledge, attitude, and behavior. J Sch Heal 1984, 54(10):385-388.

317. Ciliska D, Miles E, O'Brien MA, Turl C, Tomasik HH, Donovan U, Beyers J: The Effectiveness of Community Interventions to Increase Fruit and Vegetable Consumption in People Four Years of Age and Older. Dundas, Canada: Effective Public Health Practice Project; 1999:45. Report.

318. Chen J, Weiss S, Heyman MB, Lustig RH: Efficacy of a child-centred and family-based program in promoting healthy weight and healthy behaviors in Chinese American children: a randomized controlled study. J Public Health (Oxf Eng) 2010, 32(2):219-229.

319. Colby SE, Haldeman L: Peer-led theater as a nutrition education strategy. J Nutr Educ Behav 2007, 39(1):48-49.

320. Covelli MM: Efficacy of a school-based cardiac health promotion intervention program for African-American adolescents. Appl Nurs Res 2008, 21(4):173-180.

321. Mendoza JA, Watson K, Cullen KW: Change in dietary energy density after implementation of the Texas Public School Nutrition Policy. J Am Diet Assoc 2010, 110(3):434-440.

322. Kerr CM: A school based, interdisciplinary curriculum in grades 6 and 7 reduced obesity in girls [commentary on Gortmaker SL, Peterson K, Wiecha J, et al. Reducing obesity via a school-based interdisciplinary intervention among youth. Planet Health. ARCH PEDIATR ADOLESC MED 1999 Apr;153:409-18]. Evid-Based Nurs 2000, 3(1):13-13.

323. Haerens L, De Bourdeaudhuij I, Maes L, Vereecken C, Brug J, Deforche B: The effects of a middle-school healthy eating intervention on adolescents' fat and fruit intake and soft drinks consumption. Public Health Nutr 2007, 10(5):443-449.

324. Hendy HM, Williams KE, Camise TS, Alderman S, Ivy J, Reed J: Overweight and average-weight children equally responsive to "Kids Choice Program" to increase fruit and vegetable consumption. Appetite 2007 49(3):683-686

325. Almon M, Gonzalez J, Agatston AS, Hollar TL, Hollar D: The dietary intervention of the Healthier Options for Public Schoolchildren Study: A school-based holistic nutrition and healthy lifestyle management program for elementary-aged children. J Am Diet Assoc 2006, 106(8):A53.

326. Gonzalez J, Almon M, Agatston AS, Hollar D: The continuation and expansion of dietary interventions of the Healthier Options for Public Schoolchildren Study: a school-based holistic nutrition and healthy lifestyle management program for elementary-aged children. J Am Diet Assoc 2007, 107(Suppl 3):A76.

327. Hopper CA, Munoz KD, Gruber MB, MacConnie S: A school-based cardiovascular exercise and nutrition program with parent participation: an evaluation study. Child Health Care 1996, 25(3):231-235.

328. Jimenez MM: Evaluation of DIETARY CHANGE AMONG KAHNAWAKe Schools Diabetes Prevention Project Participating Children (grades 4-6). Canada: McGill University (Canada); 2000:97.

329. Paradis G, Lacvesque L, Macaulay AC, Cargo M, McComber A, Kirby R, Receveur O, Kishchuk N, Potvin L: Impact of a diabetes prevention program on body size, physical activity, and diet among Kanien'keha':ka (Mohawk) children 6 to 11 years old: 8-year results from the Kahnawake Schools Diabetes Prevention Project. Pediatrics 2005, 115(2 Part 1):333-339.

330. Latimer $M$, Wengreen $H$, Vitale $T$ : The role of sensory-based, vegetablethemed education in increasing vegetable consumption in elementary school-aged children. J Am Diet Assoc 2009, 109(9, Supplement 1):A54-A54.

331. Lautenschlager-Beckman LL, Smith C: An evaluation of inner-city youth garden program participants' dietary behavior and garden and nutrition knowledge. J Agric Educ 2008, 49(4):11-24.

332. Lytle LA, Kubik MY, Perry C, Story M, Birnbaum AS, Murray DM: Influencing healthful food choices in school and home environments: results from the TEENS study. Prev Med 2006, 43(1):8-13.

333. Frenn M: Peer leaders and adolescents participating in a multicomponent school based nutrition intervention had dietary improvements. Evid Based Nurs 2003, 6(2):44-44.

334. McCormick A, Kattelmann K, Ren C, Richards A, Wells K: "Fun Fruit and Veggie Event" Enhances Acceptance of Fruits and Vegetables in SchoolAged Children. J Am Diet Assoc 2009, 109(9, Supplement 1):A83-A83.

335. O'Neil CE, Nicklas TA: Gimme 5: an innovative, school-based nutrition intervention for high school students. J Am Diet Assoc 2002, 102(3):S93-S96.
336. Parmer S: The Effects of an Experiential Learning Model of Education on Second-Grade Students' Fruit and Vegetable Knowledge, Preference and Consumption. United States: Auburn University; 2006:121.

337. Reinaerts E, Crutzen R, Candel M, De Vries NK, De Nooijer J: Increasing fruit and vegetable intake among children: comparing long-term effects of a free distribution and a multicomponent program. Health Educ Res 2008, 23(6):987-996.

338. Tak N, te Velde S, Singh A, Brug J: The effects of a fruit and vegetable promotion intervention on unhealthy snacks during mid-morning school breaks: Results of the Dutch Schoolgruiten Project. J Human Nutr Diet Off J Br Diet Assoc 2010, 23(6):609-615.

339. Tak NI, te Velde SJ, Brug J: Ethnic differences in 1-year follow-up effect of the Dutch Schoolgruiten Project - promoting fruit and vegetable consumption among primary-school children. Public Health Nutr 2007, 10(12):1497-1507.

340. Evans AE, Dave J, Tanner A, Duhe S, Condrasky M, Wilson D, Griffin S, Palmer M, Evans M: Changing the home nutrition environment: effects of a nutrition and media literacy pilot intervention. Fam Community Health 2006, 29(1):43-54.

341. Taylor RW, McAuley KA, Barbezat W, Farmer VL, Williams SM, Mann JI: Twoyear follow-up of an obesity prevention initiative in children: the APPLE project. Am J Clin Nutr 2008, 88(5):1371-1377.

342. Thomas H, et al: In Interventions to Increase Physical Activity and Nutritional Intake in Children and Youth. Edited by Thomas H. Hamilton: Effective Public Health Practice Project; 2004.

343. Baranowski T, Allen DD, Masse LC, Wilson M: Does participation in an intervention affect responses on self-report questionnaires? Heal Educ Res 2006, 21(Suppl 1):i98-i109.

344. Wardle J, Herrera ML, Cooke L, Gibson EL: Modifying children's food preferences: the effects of exposure and reward on acceptance of an unfamiliar vegetable. Eur J Clin Nutr 2003, 57(2):341-348.

345. Wrigley N, Warm D, Margetts B: Deprivation, diet, and food-retail access: findings from the Leeds 'food deserts' study. Environ Plan A 2003, 35(1):151-188.

346. Crockett SJ, Mullis R, Perry CL: Parent nutrition education: a conceptual model. J Sch Heal 1988, 58(2):53-57.

347. Armstrong R, Hall BJ, Doyle J, Waters E: Cochrane update. 'Scoping the scope' of a cochrane review. J Public Health 2011, 33(1):147-150.

doi:10.1186/1471-2458-12-711

Cite this article as: Ganann et al.: Community-based interventions for enhancing access to or consumption of fruit and vegetables among five to 18-year olds: a scoping review. BMC Public Health 2012 12:711.

\section{Submit your next manuscript to BioMed Central and take full advantage of:}

- Convenient online submission

- Thorough peer review

- No space constraints or color figure charges

- Immediate publication on acceptance

- Inclusion in PubMed, CAS, Scopus and Google Scholar

- Research which is freely available for redistribution 